\title{
Trends in Educational Research about e-Learning: A Systematic Literature Review (2009-2018)
}

\author{
Jesús Valverde-Berrocoso ${ }^{1, * \mathbb{C}}$, María del Carmen Garrido-Arroyo ${ }^{1}$, Carmen Burgos-Videla ${ }^{2}$ and \\ María Belén Morales-Cevallos ${ }^{3}$ \\ 1 Department of Education Sciences, Faculty of Teacher Education, University of Extremadura, Avenida de la \\ Universidad s/n, 10003 Cáceres, Spain; cargarri@unex.es \\ 2 Director of Instituto de Investigaciones en Ciencias Sociales y Educación, University of Atacama, \\ Avenida Copayapu \#485, Campus Rómulo J. Peña, Copiapó 1530000, Chile; carmen.burgos@uda.cl \\ 3 Faculty of Philosophy, Arts and Education Sciences, Catholic University of Santiago de Guayaquil, \\ Avenida Presidente Carlos Julio Arosemena Tola, Guayaquil 090615, Ecuador; mabelenmorales0@gmail.com \\ * Correspondence: jevabe@unex.es
}

Received: 27 May 2020; Accepted: 22 June 2020; Published: 24 June 2020

check for updates

\begin{abstract}
The concept of e-learning is a technology-mediated learning approach of great potential from the educational perspective and it has been one of the main research lines of Educational Technology in the last decades. The aim of the present systematic literature review (SLR) was to identify (a) the research topics; (b) the most relevant theories; (c) the most researched modalities; and (d) the research methodologies used. To this end, the PRISMA protocol was followed, and different tools were used for the bibliographic management and text-mining. The literature selection was carried out in three first-quartile journals indexed in JCR-SSCI specialized in Educational Technology. A total of 248 articles composed the final sample. The analysis of the texts identified three main nodes: (a) online students; (b) online teachers; and (c) curriculum-interactive learning environments. It was revealed that MOOC was the most researched e-learning modality. The Community of Inquiry and the Technological Acceptance Model, were the most used theories in the analyzed studies. The most frequent methodology was case study. Finally, the conclusions regarding the objectives of our SRL are presented: Main themes and research sub-themes, most researched e-learning modality, most relevant theoretical frameworks on e-learning, and typologies of research methodologies.
\end{abstract}

Keywords: e-learning; educational technology; educational research; text-mining; systematic literature review

\section{Introduction}

The digital transformation of education systems in all levels has allowed incorporating a new teaching-learning ecosystem called e-learning. The COVID-19 pandemic caused the closing of classrooms all over the world and forced 1.5 billion students and 63 million educators $[1,2]$ to suddenly modify their face-to-face academic practices, wherever possible. This situation showed the strengths and weaknesses of education systems facing the challenge of digitalization. The digital breach is still a reality. According to data provided by the World Bank [3], in the year 2018, 84\% of the citizens of member states of the European Union had access to the Internet, compared to $66 \%$ in Latin America and $18 \%$ in the least developed countries (LDC). Bates [4] states that COVID-19 has demonstrated the current inequalities in the system and the need for universal and low-cost access to the Internet for education. This failure cannot be attributed to e-learning itself, but to the fact that the potential of this teaching method has been underestimated and excluded from the digital education projects of educational organizations. The future of e-learning must be built on principles of openness and 
equality with an education in digital competence [5]. From an economic point of view, the industry of e-learning has developed considerably in the last decade. According to Statista [6], the market of e-learning all over the world will be over 243 billion dollars in 2022.

The sustainable development is defined as development that meets the needs of the present without compromising the ability of future generations to meet their own needs (p. 43 [7]). Sustainability is a long-term, perpetual developmental process with three interconnected dimensions: Economic, environmental, and social. Discourse around sustainability in education has developed in two directions: (a) Education for sustainability that focuses on environmental sustainability through educational practices; and (b) sustainability of education that focuses on the implementation of sustainable forms of successful practice through educational development, leadership, and innovation. In this second meaning, the sustainability is the property of e-learning practice that evidently addresses current educational needs and accommodates continuous adaptation to change, without outrunning its resource base or receding in effectiveness. (p. 95 [8]). The three pillars of sustainable e-learning are: (a) Resource Management (cost of e-learning), (b) Educational Attainment (measures of student achievement, retention rates, skill acquisition, and personal development), and (c) Professional Development and Innovation (strategies for adapting to change) [8]. Diverse studies have identified three principles and nine framework elements for sustainable e-learning design: (a) Stakeholder-centeredness: (1) A labor market-driven programming agenda; (2) a continuous improvement quality assurance system; and (3) international program standards; (b) cost-effectiveness: (4) A costing model; (5) course rationalization; and (6) a learning object repository, and lastly, (c) high operational efficiency: (7) Template-based document preparation; (8) project management; and (9) an electronic project work-space. [9-11].

\subsection{Definition of e-Learning}

Aparicio et al. [12] claim that e-learning concept was not the first term to be used in conceptualizing the use of computerized systems to enable or facilitate the learning process. They identified 23 concepts that belong to the use of computers for learning purposes (e.g., online learning, virtual learning, distance education, m-learning, MOOC, learning management systems). E-learning should not be confused with the concept blended learning, which is defined as the effective integration, fusion even, of face-to-face and online learning depending on the educational need and purpose (p. 200 [13]). Sangrà et al. [14] found four general categories of definitions of e-learning: (1) Technology-driven: Use of technology to deliver learning and training programs; (2) delivery-system-oriented: The delivery of a learning, training, or education program by electronic means; (3) communication-oriented: Learning facilitated by the use of digital tools and content that involves some form of interactivity, which may include online interaction between the learner and their teacher or peers; and (4) educational-paradigm-oriented: Information and communication technologies used to support students to improve their learning. Rodrigues et al. [15] define e-learning as an innovative web-based system based on digital technologies and other forms of educational materials whose primary goal is to provide students with a personalized, learner-centered, open, enjoyable, and interactive learning environment supporting and enhancing the learning processes (p. 95). Garrison [16] claims that e-learning is a disruptive technology that is currently transforming how learning is approached in an educational context (p. 21). Dron and Anderson [17] identified four generations of e-learning pedagogies: The behaviorist/cognitivist, the social constructivist, the connectivist, and the holistic generation. The relevance of each pedagogical approach depends on the technological capabilities that it uses. The holistic generation includes: Learning analytics, collective technologies, deep learning and artificial intelligence, disaggregated tools and services, mobility and device diversity, the internet of things and ubiquitous computing, virtual and augmented reality, and 3D printing. The characteristics of this next generation of pedagogies are: (a) Student-centered; (b) distributed technically, socially, and organizationally; (c) crowd-driven support and emergent; (d) integrated, just-in-time, and authentic; (e) courses will play a less significant role; and (f) learning will be separate from accreditation. 
Njenga and Fourie [18] identified 10 myths about e-learning in higher education, extracted from the emerging educational practice, information provided by technology providers, and the academic literature: (1) E-learning is a very powerful instrument and all educational institutions should adopt it; (2) e-learning may replace human interaction; (3) e-learning reduces the economic costs of education; (4) increasing the academic offer and large amounts of information are beneficial for learning; (5) digital technologies should be the main learning means or resource in higher education; (6) leisure (including games and entertainment) and learning are separate activities; (7) e-learning will make university institutions more competitive; (8) defining the infrastructure (hardware and software) in e-learning is the most difficult task; (9) e-learning will be the end of traditional campuses; and (10) e-learning may decrease absenteeism and the dropout rates among university students.

This systematic literature review (SLR) aims to contribute to the deconstruction of these and other myths that have emerged around e-learning, by approaching the research conducted in this regard in the last decade. This allowed for identifying the main study themes and research lines that provide scientific knowledge about the present and future of this educational technology.

\subsection{Previous SLRs about e-Learning Research}

Previous reviews about educational research on e-learning allows observing the evolution of this study theme in the scope of educational technology (Table 1). Regarding the methodology applied in the reviews, it is important to highlight that, except for the study conducted by Zare et al. [19], none of them reported the application of the PRISMA protocol in their development.

Table 1. Documentary search terms for previous systematic literature reviews (SLRs) about e-learning.

\begin{tabular}{cccc}
\hline Date & Search Term & Database & N. $^{\circ}$ of Results \\
\hline 23-07-2019 & $\begin{array}{c}\text { TITLE e-learning) AND TITLE (“systematic review”)) AND } \\
\text { DOCTYPE (ar) AND PUBYEAR > 1999 }\end{array}$ & SCOPUS & 6 \\
\hline $23-07-2019$ & $\begin{array}{c}\text { TITLE: (e-learning) AND TITLE: (“systematic review”) Date } \\
\text { range (inclusive): 2000-2019. Index: SSCI, ESCI. }\end{array}$ & WOS & 15 \\
\hline $23-07-2019$ & $\begin{array}{c}\text { (TITLE (e-learning) AND TITLE (“trends”)) AND DOCTYPE } \\
(\text { ar) AND PUBYEAR > 1999 }\end{array}$ & SCOPUS & 22 \\
\hline 23-07-2019 & $\begin{array}{r}\text { TITLE: (e-learning) AND TITLE: (“trends”) } \\
\text { Date range (inclusive): 2000-2019. Index: SSCI, ESCI. }\end{array}$ & WOS & 11 \\
\hline
\end{tabular}

Source: developed by author.

Conole and Oliver [20] grouped the publications about e-learning into four dimensions: Pedagogical, technical, organizational, and sociocultural. In the period of 2002-2004, studies in this field are characterized for making a general description of the concept of e-learning and its practice within a large variety of aspects. In a second phase (2007-2008), the research themes were reduced, and studies were oriented toward the technical aspects of e-learning in its educational applications: Systems and models, case studies, and teaching-learning strategies, among other.

Shih et al. [21] carried out an SLR about trends in the research about cognition and e-learning (2001-2005) from a selection of five scientific journals indexed in SSCI (Social Sciences Citation Index) within the scope of educational technology. They analyzed a total of 444 articles, identifying seven categories (motivation, information processing, instructional approach, learning environment, prior knowledge, metacognition, and cognitive-psychological characteristics). The most researched themes were learning environment-interactive learning environment, instructional approach-collaborative learning, and metacognition-perception and awareness.

The systematic review of Rodrigues et al. [15] was focused on the concepts of e-learning and education in the ABI-Inform and EBSCO databases. For the analysis of the data, they used a text mining software. As in our study, these tools specialized in the analysis of texts prove to be essential for a quality SLR. The identified dimensions were education (educational technology trends, online tools, and social media), learning issues (innovation in educational fields, online platforms, and learning styles), 
student (behavioral issues: Engagement, satisfaction, and motivation), and usability (distance learning, e-learning systems, and learning analytics).

Maurer and Khan [22] conducted an SLR about a selection of five scientific journals and two conferences with the aim of identifying the trends in the research on e-learning in the period of 2003-2008. They used the gCLUTO software (graphical application for clustering datasets) in order to carry out a scientometric and content analysis. The identified categories were instructional/educational technology, instructional process, teaching/learning perspectives, instructional methods, delivery systems, instructional development, production variables, learner, learning environment, evaluation, culture, and teacher.

Oncu and Cakir [23] identified four priorities in the research about online learning environments: (1) Enhancing learner engagement and collaboration; (2) promoting effective facilitation; (3) developing assessment techniques; and (4) designing faculty development programs. These areas are directly related to the dependent variables that should be the object of study in the research on e-learning: learner achievement, learner engagement, and learner retention. In this proposition, we observed a coincidence with the results of our SLR, which identified these variables as concepts that have been objects of study in the analyzed publications of the period of 2009-2018. Furthermore, all the priorities are reflected in our nodes and subnodes. With regard to the research methodologies, these authors defend the following methodological approaches: formative research (aimed to improve the instructional design and all the curricular components), developmental research, experimental research, and activity theory.

In their SLR, Zare et al. [19] used five databases of scientific publications and the focus of their review was the identification of studies about e-learning and MCDM (multi-criteria decision making), which is an efficient approach for evaluating multiple criteria. As a result, the following criteria in e-learning evaluation were identified: usability; response-time; interactivity, web \& course design, accessibility, reliability, cost-effectiveness, functionality, security, stability trust, accuracy, flexibility, interoperability, and continuity.

As a condition for the success of online education, it is fundamental to promote an educational research line that develops efficient pedagogical designs that facilitate the learning of competencies. The aim of this SLR was to analyze the evolution of educational research on e-learning in order to identify patterns in the studied themes, determine the predominant methodological perspectives, and value the transferability of this knowledge in the university teaching practice. This SLR provides an evolution of the educational research conducted on e-learning throughout a decade, allowing the identification of the main interests of the scientific community, the approaches used to tackle these online educational phenomena, and their impact on the digital transformation of education. The objectives of this SLR were the following:

1. To identify the research topics about e-learning and education that were published in international high-impact scientific journals in the period of 2009-2018.

2. To reveal the educational theories about e-learning that were used in international high-impact scientific journals in the period of 2009-2018.

3. To determine the most used e-learning modality in studies published in international high-impact scientific journals in the period of 2009-2018.

4. To identify the methodologies of educational research used in studies published in international high-impact scientific journals in the period of 2009-2018.

\section{Materials and Methods}

Firstly, a specific preliminary documentary search was conducted with the aim of identifying previous SLRs about the concept of e-learning. The following table presents the search terms and databases used and the number of results obtained. Of the total of 54 articles found, six were selected, whose main objective was to identify the research lines or trends in e-learning [15,19-23]. This preliminary search and selection showed the need to carry out a SLR focused on analyzing the 
research trends on e-learning in the period of 2009-2018. The previous SLRs were carried out between the years 2001-2005 [21] and 2003-2008 [22].

Thus, a SLR was conducted using the SCOPUS database and following the PRISMA protocol [24,25]. With the aim of estimating the total duration of the process of conducting this SLR, the online software PredicTER was used. Figure 1 gathers the graphs of the prediction of temporal development of the SLR as a function of different parameters (Planning; Searching; Screening; Data Extraction; Appraisal and Synthesis; Reporting).

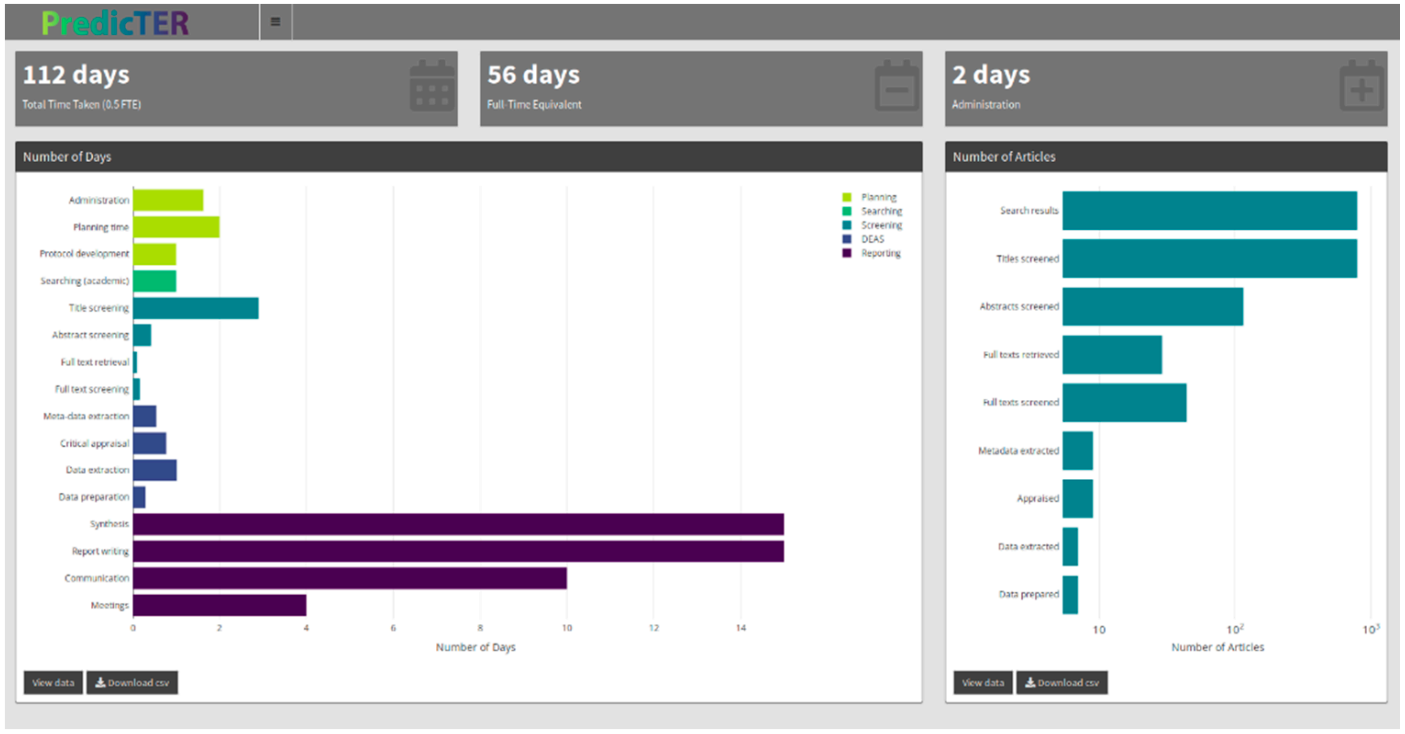

Figure 1. Estimation of the time required to conduct this SLR. Source: Developed with the online software «PredicTER» (https://estech.shinyapps.io/predicter/).

For the selection of keywords, the term Electronic Learning was used, based on its inclusion in Thesaurus ERIC and its identification as a preferential concept over other terms such as online learning or mobile learning. In the documentary search, the synonym e-learning was used, for being the most widely used in the specialized literature. The review was limited to scientific journals specialized in educational technology, rated Q1 in the Journal Citations Reports (JCR) in the analyzed period (2009-2018) with a first-quartile presence percentage of $80 \%$ or higher and within the category of Education \& Educational Research: Computers \& Education (100\%), British Journal of Educational Technology (100\%) and Internet and Higher Education (80\%). The sequence of filters used in SCOPUS was the following: ISSN (...) AND KEY (e-learning)) AND DOCTYPE (ar) AND PUBYEAR > 2008 AND PUBYEAR $<2019$.

The inclusion-exclusion criteria established were the following: Articles published in the selected scientific journals (British Journal of Educational Technology-BJET, Computers \& Education-C\&E, The Internet and Higher Education-I\&HE), including articles «in press», in English, and published within the period between January 2009 and December 2018 (Table 2). The criteria included theoretical and empirical studies with quantitative and/or qualitative methods whose main topic was educational research on e-learning. For the compilation and management of documentary databases, the free bibliographic-management software Zotero was used. In addition to the metadata of each article, including the abstract and keywords (when applicable), the complete text in PDF was added to the database of Zotero.

For the SLR, CADIMA [26] was used, which is an open access online tool designed to: (1) Assist throughout the systematic review/map process; (2) allow for offline data extraction; and (3) support the work of the review team. CADIMA meets the standards of PRISMA (Figure 2). 
Table 2. Documentary search terms for the SLR.

\begin{tabular}{cc}
\hline Search Terms & Database \\
\hline ISSN (10,967,516) AND KEY (e-learning)) AND DOCTYPE (ar) AND PUBYEAR $>2008$ ND PUBYEAR $<2019$ & SCOPUS \\
ISSN (0360-1315) AND KEY (e-learning)) AND DOCTYPE (ar) AND PUBYEAR > 2008 AND PUBYEAR $<2019$ & SCOPUS \\
ISSN (0007-1013) AND KEY (e-learning)) AND DOCTYPE (ar) AND PUBYEAR $>2008$ AND PUBYEAR $<2019$ & SCOPUS \\
\hline
\end{tabular}

Source: developed by author.

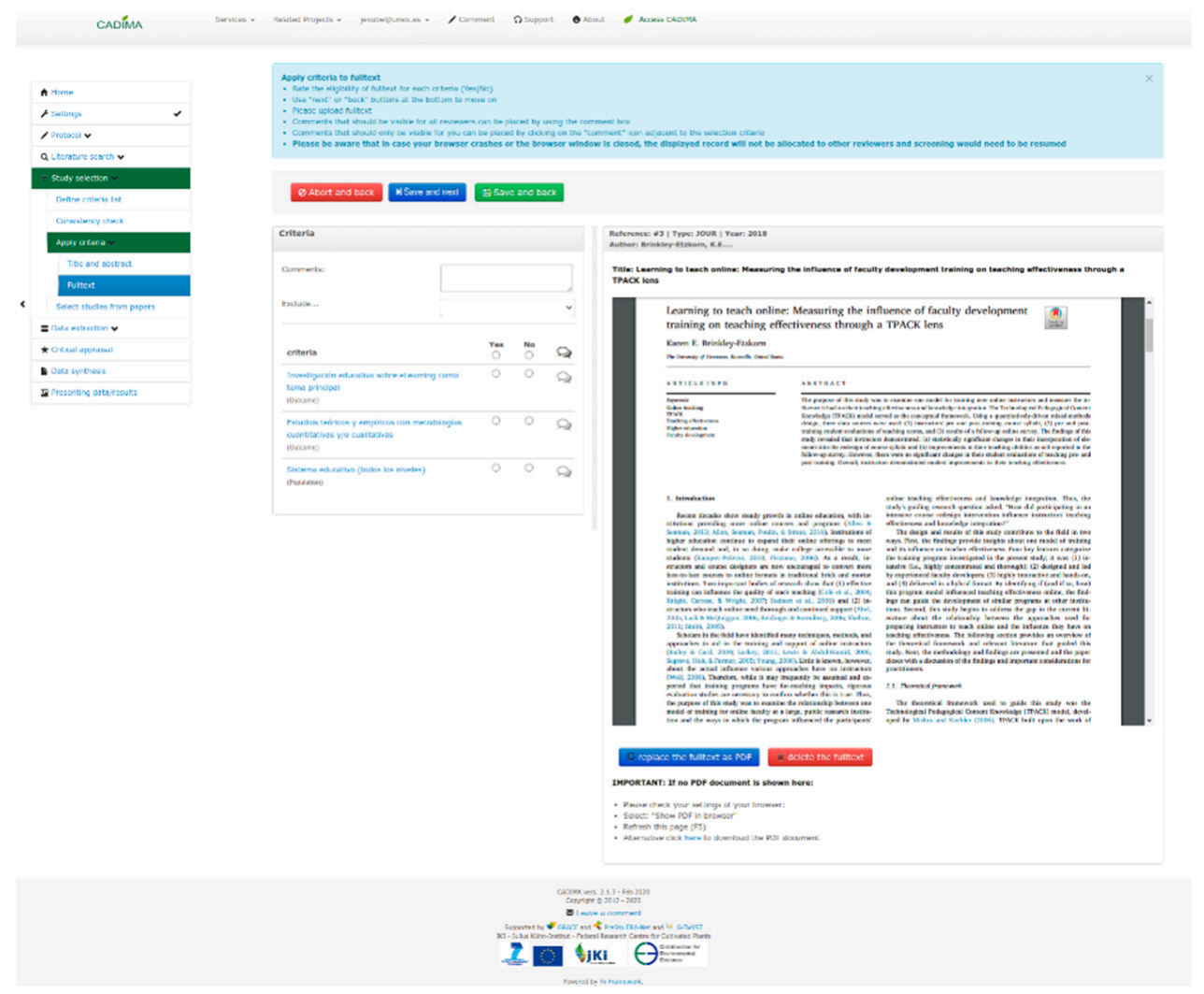

Figure 2. CADIMA, SLR online software. Source: Developed by author.

Firstly, the protocol was introduced: Title page, background, objective, methods (search strategy, study selection, critical appraisal, data extraction, and data analysis), competing interests, timeline, author's contributions, acknowledgements, and appendices. Then, the literature search was conducted: Definition search string(s) and display merged reference list. Once the documentary database was filtered, the study selection was carried out: Define criteria list, consistency check, apply criteria, and select studies from papers. The data were extracted using NVivo 12 Plus.

In the first phase, the inclusion criteria were applied to the title and abstract. In the second phase, the inclusion criteria were applied to the full text. Two independent reviewers acted in the different phases: (1) Selection based on inclusion criteria and (2) ultimate inclusion in the review. In the first phase, a Cohen's kappa coefficient [27] of 0.9 was obtained, considering an «almost perfect» concordance index between the evaluators [28]. The discrepancies were resolved by later agreement. As a result of the processing of the 790 articles selected initially, 498 of these were excluded for not meeting the inclusion criteria, in terms of title and abstract. The full text of the remaining 292 articles was evaluated, after which a total of 44 articles were excluded for being focused on «blended learning». Therefore, the final sample consisted of 248 articles (Figure 3). 


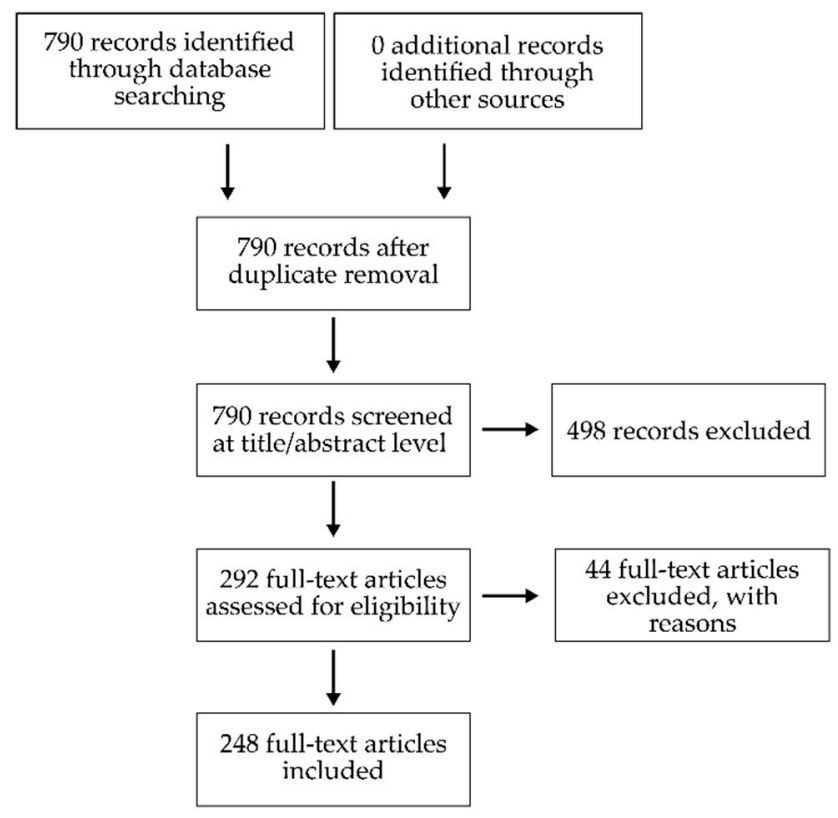

Figure 3. Flow diagram. Source: Developed by author from CADIMA.

The coding process began by addressing the most frequent concepts of the selected articles using VOSViewer, which is a software tool for creating maps based on network data and for visualizing and exploring these maps [29]. For a total of 545 keywords, the limit was established at 33 keywords, with a minimum concurrence of 5 keywords. Three clusters were identified, constituted by 15 (red), 14 (green), and 4 (blue) keywords, respectively (Figure 4).

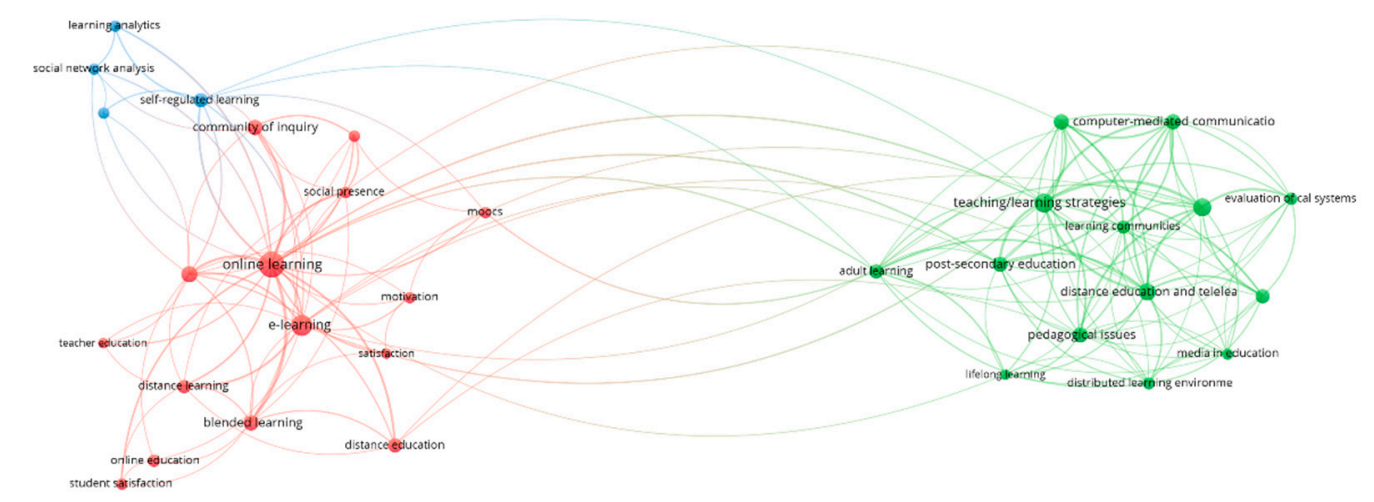

我 vosviewer

Figure 4. Network visualization of concepts. Source: Developed by author using VOSViewer (v.1.6.15).

Then, categories and subcategories (issues) were generated using the NVivo 12 Plus software. To this end, a RIS file was imported from the bibliographic manager Zotero. The 248 articles selected after concluding the two valuation phases were introduced in NVivo. An automatic coding was applied, obtaining a total of 10 main concepts with their corresponding terms. These were analyzed using the word tree to identify the most frequent terms, and they were also compared with the map of correlations obtained with VOSViewer. Then, using the NVivo tool Text Search, the concepts revealed in the previous phase were searched and coded in nodes (subcategories). From this relation of issues, the main nodes were defined (categories). Next, the NVivo tool Matrix coding query was used to identify the articles that include each node in their content. This analysis allowed identifying 
the most relevant article of each node, through the frequency of their presence in the texts. Lastly, using the NVivo tool Crosstab query, we analyzed the relationships between the nodes and some of the fields present in the classification of the references (articles), such as authors, years, and journals. Furthermore, a complementary analysis was carried out, exclusively focused on the keywords of the journals C\&E and I\&HE, since BJET does not include them. A single file with the list of keywords was analyzed using the NVivo tools to identify research themes about e-learning.

\section{Results}

In accordance with the objectives of the study, the results of the SRL are presented below (see Appendix A). Different graphic representations of the data are introduced, which have been considered necessary to support our results.

\subsection{Research Themes and Subthemes about e-Learning and Education (2009-2018)}

The analysis of the keywords provided a first view of the research themes that are present in the articles selected for this SLR $(n=248)$. Firstly, the cluster analysis generated the following dendrogram (Figure 5), where possible categories and subcategories are identified by word similarity.

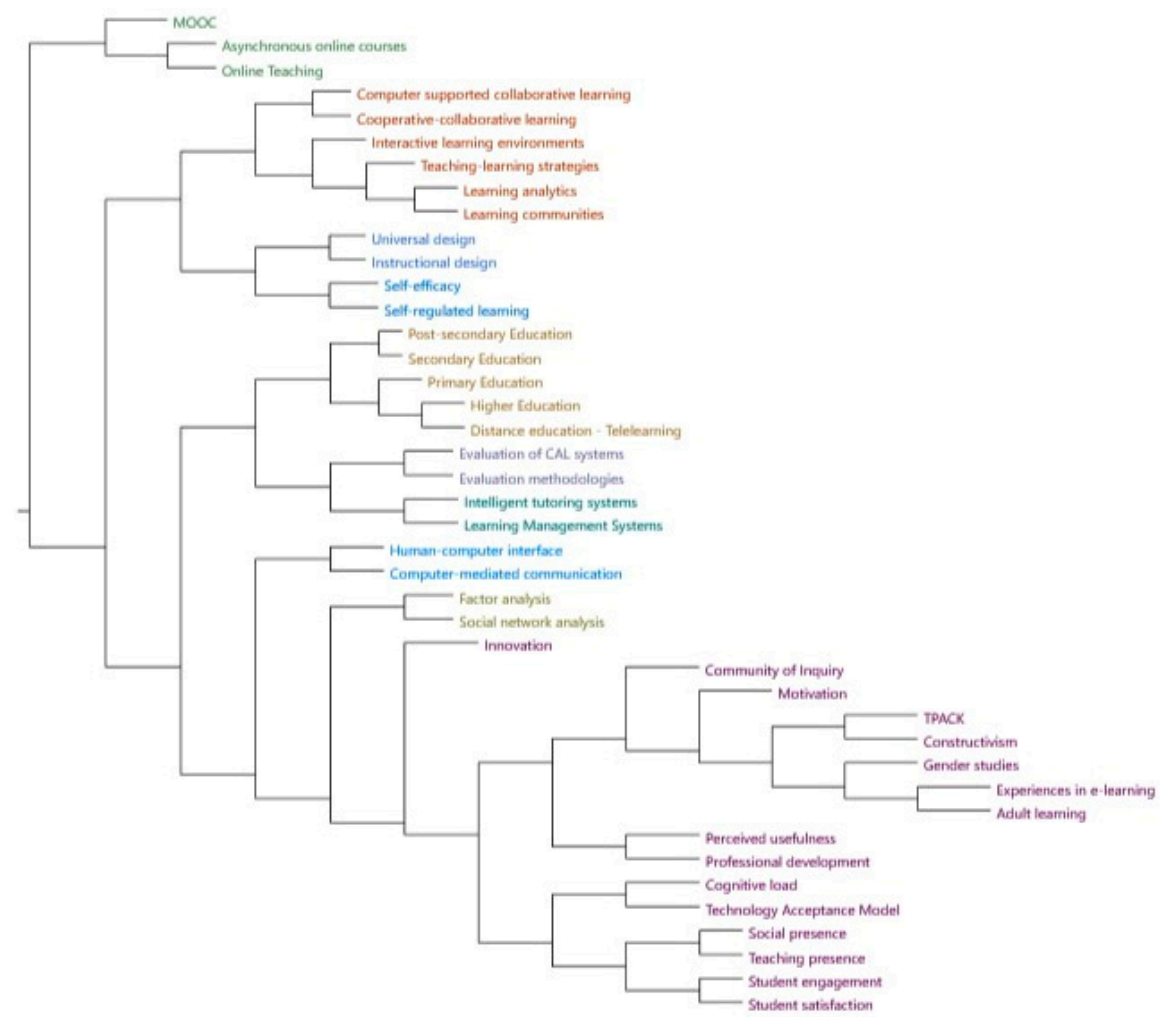

Figure 5. Cluster analysis of keywords (dendogram). Source: Developed by author using NVivo.

More specifically, this dendrogram shows the relevance of each of the keywords with the use of a hierarchy chart, which allows observing patterns through a tree map (Figure 6). The most frequent keywords in e-learning research are identified: MOOC, higher education, teaching-learning strategies, and interactive learning environments, which are revealed as main concepts. 


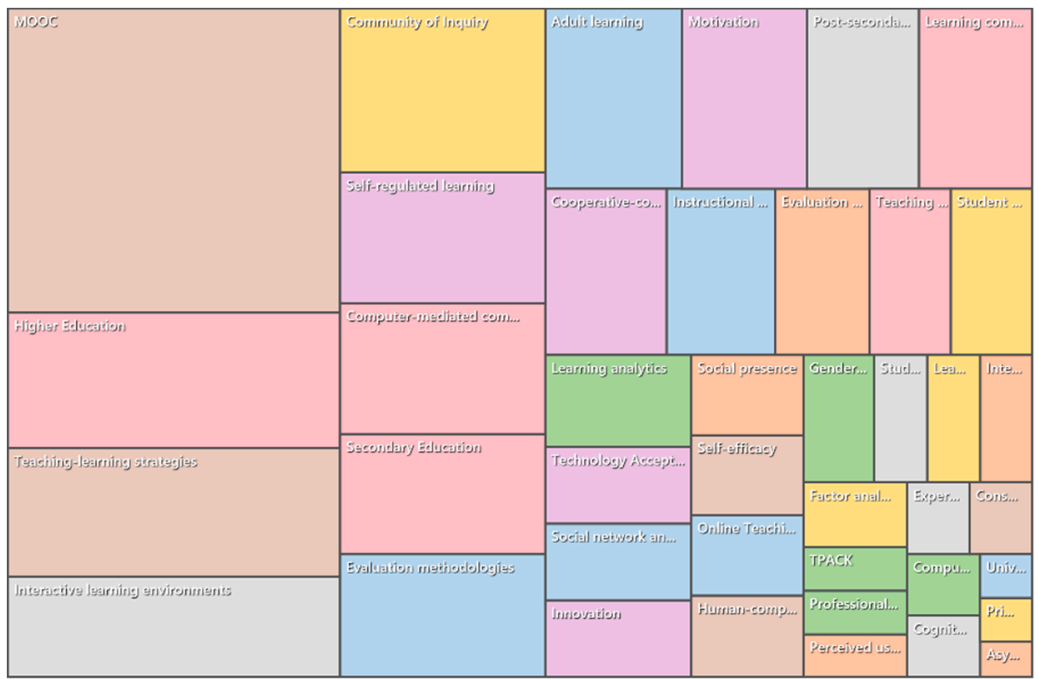

Figure 6. Hierarchy chart of keywords. Source: Developed by author using NVivo.

Based on this hierarchy and its conceptual relationships, it is possible to establish a series of levels in the identification of themes and subthemes of educational research on e-learning, as well as links between concepts. Thus, MOOC is especially associated with learning analytics and social networks analysis. The first-level keyword higher education is associated with other educational levels, such as secondary education, which is the second most studied level, adult learning, and post-secondary education, which are in the third level, and lastly gender studies, which has a very poor representation in this sample of articles. The first-level keyword interactive learning environments is associated with two widely studied concepts: community of inquiry (CoI) and computer-mediated communication (level 2). Although, at the third level, learning communities and instructional design are also related. One of the components of CoI, teaching presence, is in the fourth level, along with evaluation of CAL system and technology acceptance model (TAM). The lowest (fifth) level includes by social presence (CoI), human-computer interface, intelligent tutoring system, and learning management systems (LMS). The first-level concept teaching-learning strategies is correlated with the second-level keywords evaluation methodologies and self-regulated learning, which were widely studied in the analyzed period. The third level includes motivation and cooperative-collaborative learning. With lower frequency, student satisfaction and innovation fall into the fourth level. Lastly, self-efficacy and student engagement are identified as the keywords with the lowest presence. Figure 7 represents this level of hierarchy and the thematic links between the main keywords of the analyzed articles.

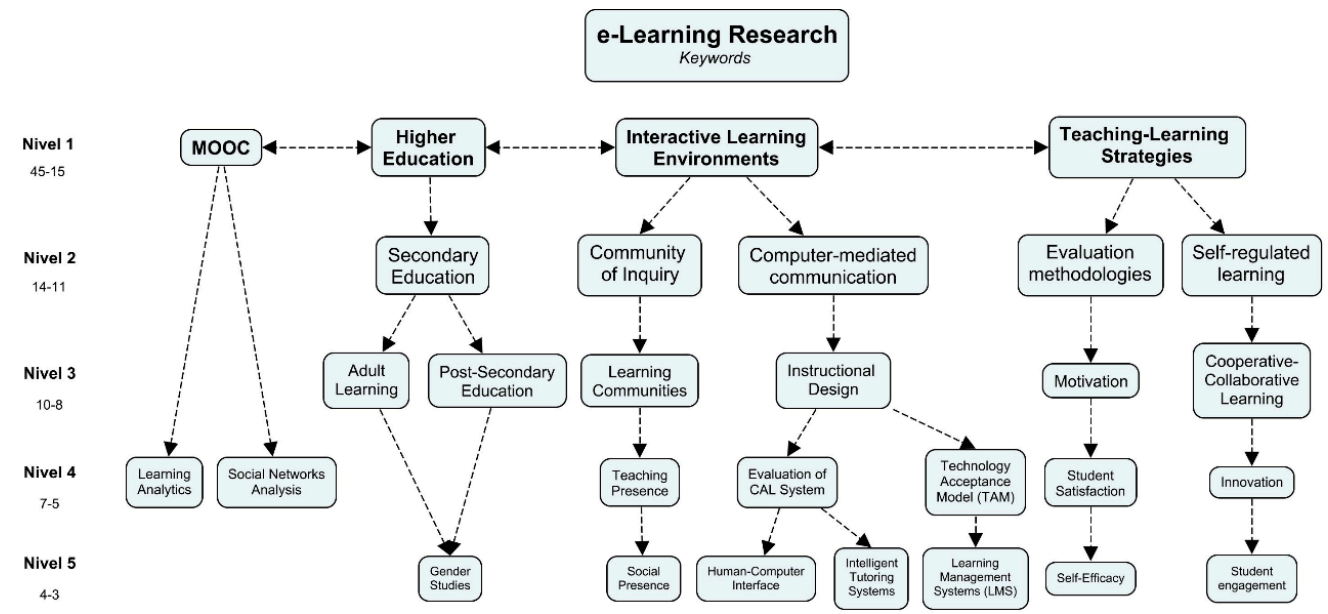

Figure 7. Map of levels and thematic relationships between keywords. Source: Developed by author using CMapTools. 
The coding of the full-text articles generated three main nodes: (a) e-learning \& online students; (b) e-learning \& online teachers; and (c) e-learning \& curriculum. The rest of the nodes identified are tackled in further sections, as they respond to different objectives (theoretical frameworks, e-learning models, and research methodologies).

The e-learning \& online students node includes two relevant themes with similar representation: self-regulation and dropout \& retention (Figure 8). Self-regulation was observed to have a positive influence on educational performance and interaction; its presence is fostered in active learning environments that are perceived as useful and satisfactory [30-33]. In the dropout \& retention subnode, researchers investigate factors that favor the retention of online students, such as the quality of the instructive design, well-developed evaluation activities consistent with the objectives of the course, opportunities of collaboration between students, proactive attitude of the teacher/faculty member in educational communication, certification of the formative activity, and guidance for future studies [34-36]. In the student satisfaction subnode, studies are focused on the influence of contextual (demographic, cultural) and psychopedagogical (cognitive load) variables on the satisfaction of students with e-learning, as well as on the identification of ideal curricular contents for a first satisfactory experience in an online environment [37-40]. In the student motivation subnode, which is strongly associated with student satisfaction, studies reveal the importance of achievement emotions as a predictor of the motivation of online students and the essential role of the teacher/faculty member to stimulate motivation toward e-learning by supporting the capacities, effort, and work value of the students [41,42]. The analysis also generated the concept of digital literacy, or the competence to plan, apply, and evaluate digital activities of daily living, as well as the capacity to reflect on these activities. In the studies on e-learning, researchers use this variable to predict self-efficacy [43]. It is also demonstrated that the differences in digital literacy between educators and students have an impact on e-learning, since the day-to-day digital competences do not match the digital competences required in the online academic environment [44]. Lastly, a set of psychopedagogical variables were also identified, which reveal different characteristics of the online students: self-efficacy [45,46]; Locus of control [47]; and Cognitive skills [48].

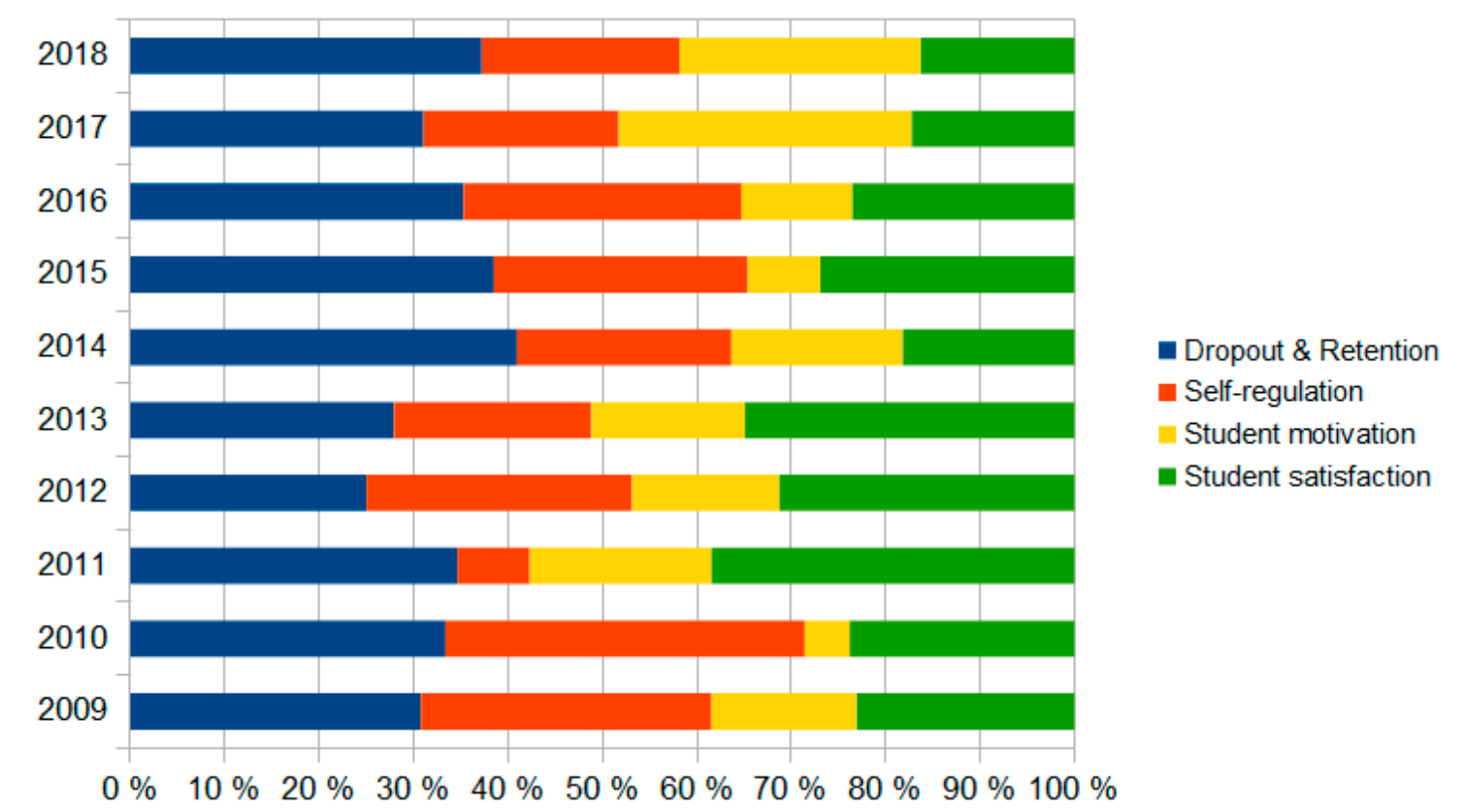

Figure 8. Percentage distribution of the subnodes of «e-learning \& online students» by years in the period of 2009-2018. Source: Developed by author.

The e-learning \& online teachers node includes two main subnodes: professional development (in-service teachers) and teacher education (pre-service teachers), both oriented toward training in 
teacher digital competence (Figure 9). The analysis identified different conceptualizations about professional development: (a) Training: Learning the use of technological tools and devices (software and hardware); (b) curricular change: Rethinking the teaching practices to provide opportunities for the reconceptualization of the teaching-learning processes and exploring the possibilities of e-learning; (c) collaboration: Every e-learning manager (ICT coordinators, educational technology advisors, support technicians, and management teams) play a role in teacher training (planning, dissemination, awareness, organization, implementation, and recognition); (d) relevance: Using e-learning to satisfy individual needs, related to specific contexts and themes, and to be available whenever needed and in the most useful, appropriate, and effective manner [49-51]. The third node in the hierarchy is teaching methodology, where researchers have reported differences between sexes, with female students giving more importance to planning and participation, whereas male students value the rhythm of teaching to a greater extent [52]. Technological tools for the instructional design of e-learning have also been valued, as well as their influence on teaching methods [53]. The teacher roles node includes studies that identify roles of online teachers: Course designer and organizer (coordination of learning activities and management of the general structure of the course); discussion facilitator (promotion of communication and feedback using synchronous and asynchronous tools); social supporter (promotion of a sense of community); technology facilitator (use of devices and tools for the promotion of learning); and assessment designer (development of online evaluation activities) [54]. With low presence, the concepts of teacher emotions, teacher attitudes, and teaching preferences were also identified.

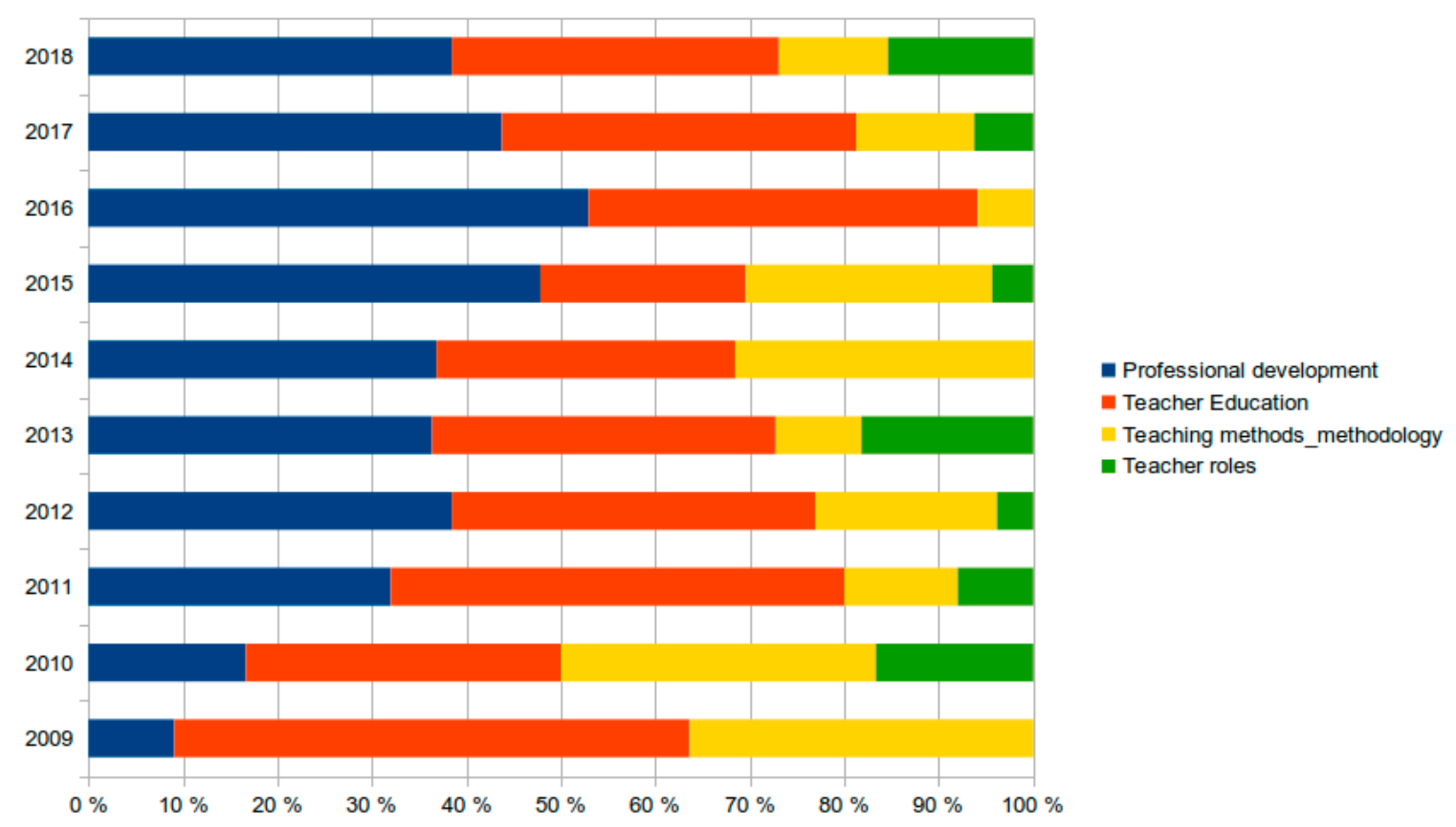

Figure 9. Percentage distribution of the subnodes of «e-learning \& online teachers» by years in the period of 2009-2018. Source: Developed by author.

Regarding the e-learning \& curriculum node, several subnodes were identified, which are described in groups to facilitate their understanding (Figure 10). The most relevant theme is the study of the impact \& success of e-learning [45,55-57], which is strongly associated with the course outcomes subnode [58,59]. The instructional design subnode includes studies about the validity and quality of the teaching models of e-learning [60-62]. Within the concept of management, three subnodes were identified: course \& learning management [63]; knowledge \& information management [64]; and time management $[65,66]$.

Assessment is another group of subnodes that includes the concepts of formative assessment, where researchers study its validity (the use of significant assessment activities that promote contextual 
learning, based on multidimensional research and perspectives) and reliability (the use of varied learning evidence and assessment rubrics), as well as the importance of immediate feedback, attention to individual needs, and the design of activities that promote critical thinking and creativity $[67,68]$. The concepts of Self-assessment [69]; Peer assessment [70], and Automated assessment [71] were also identified.

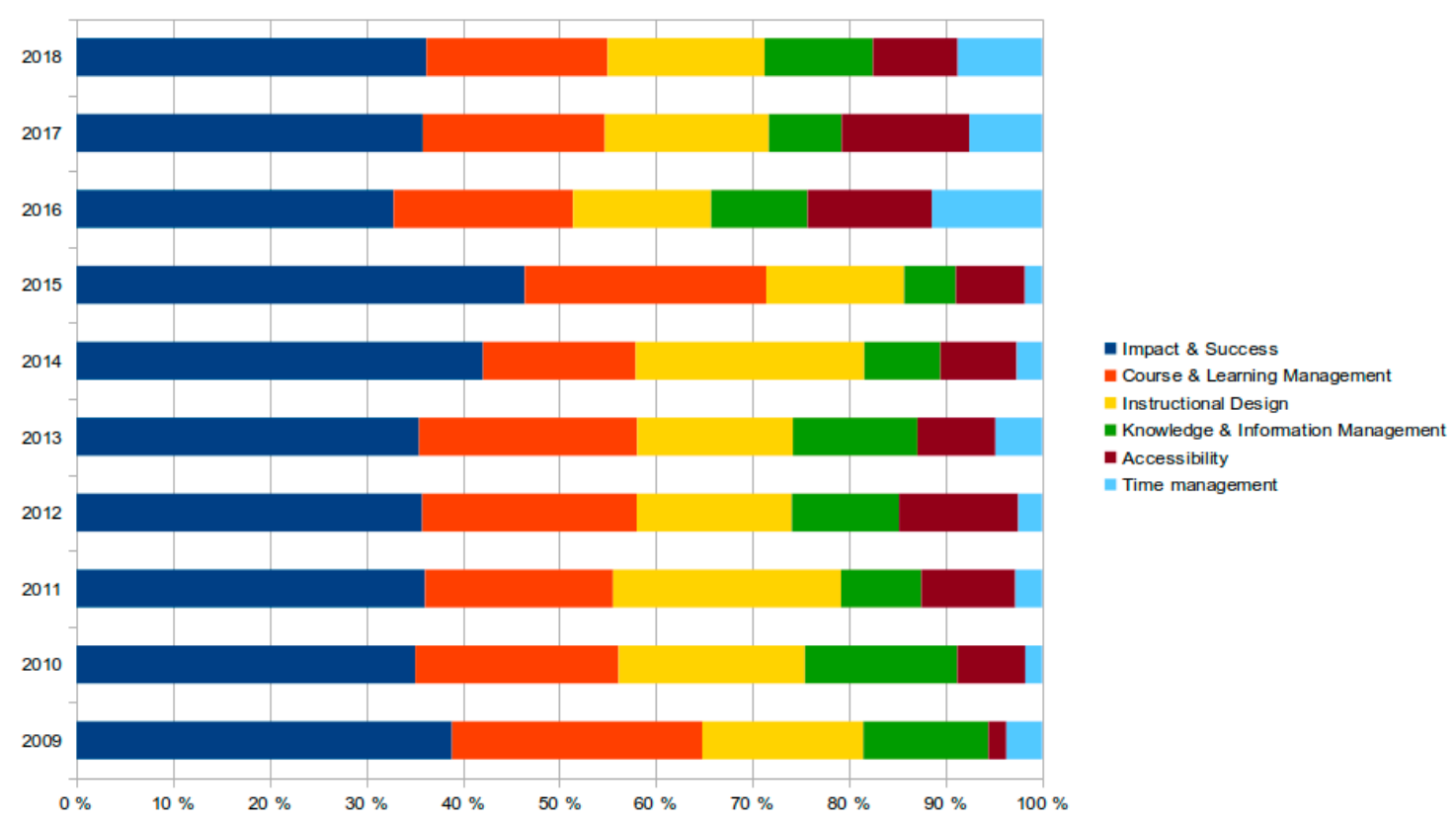

Figure 10. Percentage distribution of the subnodes of «e-learning \& curriculum» by years in the period of 2009-2018. Source: Developed by author.

\subsection{Educational Theories about e-Learning}

The most relevant theoretical framework in the studies about e-learning of this SLR is Community of Inquiry (CoI) [72,73]. A CoI is defined as a community of learners constituted by people who indistinctly take on the teacher and student roles and engage in an educational communication with the specific aim of promoting research, building meanings, and validating their understanding of the studied concepts and phenomena. These communities provide the means to integrate personal reflection and shared discussion. Their success depends on the ability to create and maintain learning environments that involve the students in meaningful learning activities and awake their interest. It is considered that the construction of individual knowledge is especially influenced by the social context. A CoI provides the context in which students can take on responsibilities and manage their learning by negotiating meanings, identifying erroneous concepts, and questioning their beliefs [74]. The components of a CoI are: (1) social presence, which is the ability of students to identify as a group, communicate openly in a context of trust and progressively develop affective and personal relationships as a way of projecting their individual personalities [75-78]; (2) teaching presence, which is defined as the design, promotion, and orientation of the cognitive and social processes to generate personally meaningful learning results of educational interest [59,78-80]; and (3) cognitive presence, or the extent to which students are capable of building and confirming meanings through constant reflection and discussion in a critical CoI [81-84]. In numerous studies, CoI Survey is used as an instrument to assess the three presences in educational contexts of e-learning [85-88].

Another theoretical model, with greater presence in the analyzed articles, is the theory acceptance model (TAM). Researchers have developed different models to predict and explain the beliefs of teachers regarding the use of digital technologies in their teaching practice. One of these models is TAM, which aims to explain the factors that influence the users of technologies [89]. TAM considers two beliefs related to the adoption of technologies: On the one hand, the perceived ease of use, that is, 
the personal belief that the use of specific technologies will reduce the effort made to complete a task and, on the other hand, the perceived usefulness, which is the personal belief that the use of technologies will improve professional performance. This model has been used in multiple studies and it has shown that these perceptions explain a relevant part of the variance in the intention of use and attitude toward digital technologies [90-93].

Figure 11 shows the increase of the relevance of $\mathrm{CoI}$ in the last year (2018) in studies about e-learning, when it reached its highest frequency in the analyzed period.

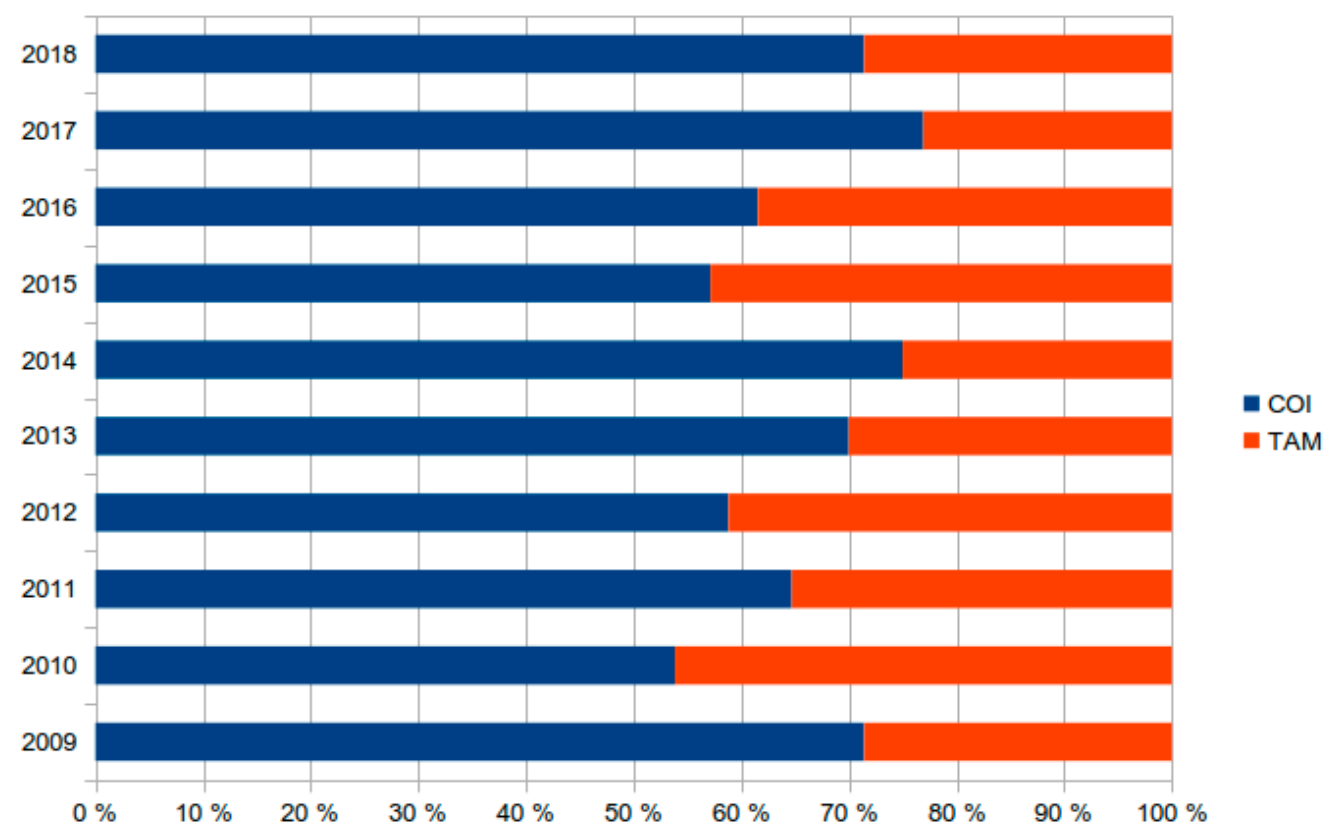

Figure 11. Yearly evolution of community of inquiry (CoI) and theory acceptance model (TAM) in the analyzed studies (2009-2018). Source: Developed by author.

\subsection{Most Studied e-Learning Modality}

Massive open online course (MOOC) is the e-learning modality with the greatest presence in the analyzed articles. MOOC is an evolution of previous experiences in the scope of open education and e-learning. Its background includes the movement for open educational resources (OER) and the pioneering initiatives in distance education with digital technology. In fact, the psychopedagogical bases of MOOC include: Distributed cognition, social constructivism, connectivism, collaborative learning, and OER. Although these have clear deficiencies related to teaching feedback, they have helped to develop the use of learning analytics and personalized education [94]. There are two categories of MOOC: (1) Networks of distributed online resources (cMOOCs), and (2) well-structured learning pathway resources centralized on MOOCs platforms (xMOOCs) [95]. Most of the analyzed articles are focused on the study of XMOOCs. The themes approached in the articles are the following (Figure 12): MOOC learners, where researchers explore demographic factors of online students, as well as barriers, potentiators, and psychological profiles [96,97]; MOOC participation, with studies that reveal the importance of expectations and motivations in the conducts and results of MOOCs, and where participating students show a combination of cognitive goals, self-assertiveness, and attainment of objectives [98-100]; MOOC completion, where learning persistence is studied, which refers to the learners' willingness to complete the learning tasks that they begin [101,102]; MOOC design, where researchers identify design factors that prove relevant for the success of a massive course [70]; and MOOC discussion, where studies show that forums are used by students with higher education level who seek support to improve professionally, thus becoming spaces of mass communication in which learning communities are not formed [103,104]. Figure 9 presents the evolution of the nodes about MOOC from its first appearance in the literature in the year 2013, showing a similar behavior 
in all the detected subnodes, that is, an important growth up to 2016, a decrease in 2017 and a new increase in 2018.

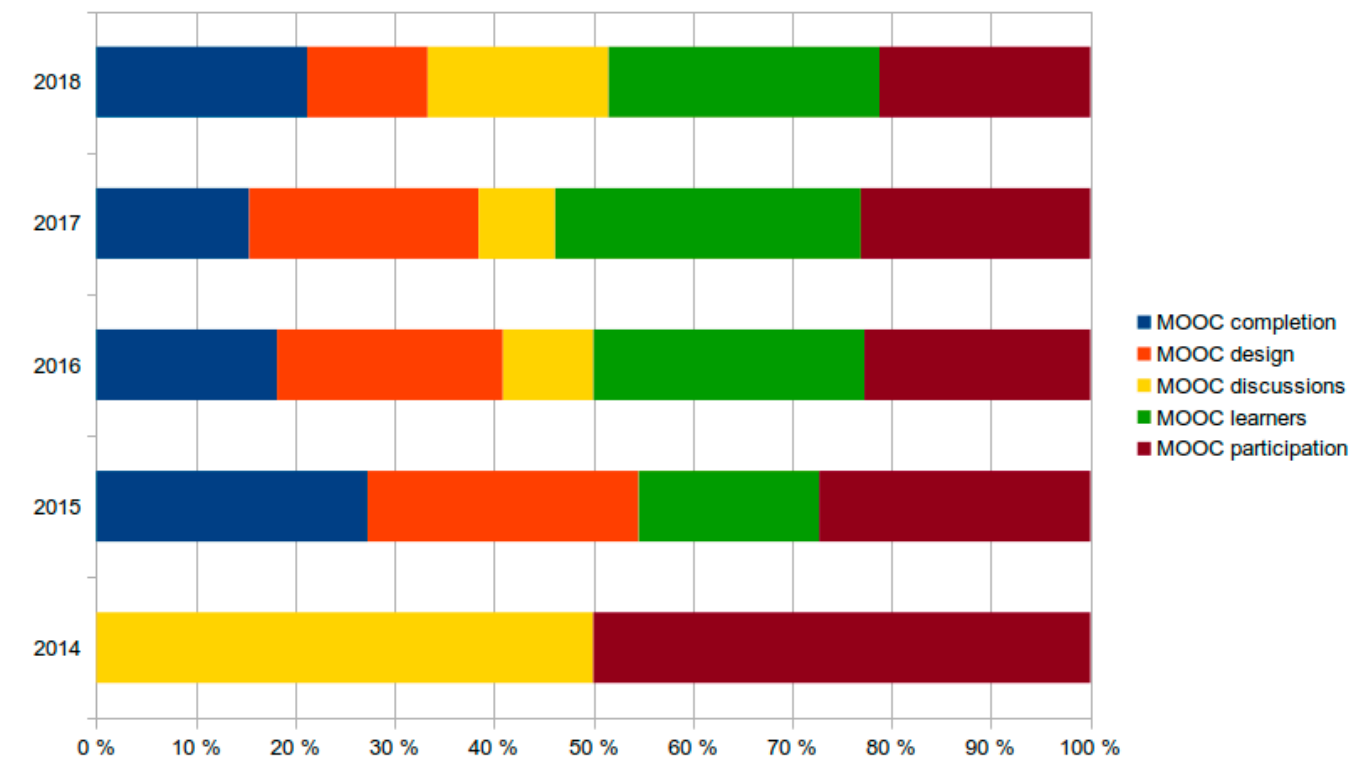

Figure 12. Evolution of the nodes of massive online open courses («MOOC») in the period of 2009-2018. Source: Developed by author.

\subsection{Research Methodologies in the Analysed Articles}

Case study is the most used methodological concept in the analyzed research articles [44,105-108]. A large number of these studies are focused on massive online open courses (MOOCs), which can be divided into two different types: (a) Observational case study, where there is no intervention and the case is described based on its activities and/or results; and (b) intervention-case study, where the only case is the ecosystem for the educational action and change [109]. It is also applied in studies about online formative assessment. Due to the complexity of the analyzed phenomena, many researchers choose the case-study methodology, with their frequent participation in the formative action as teachers and/or instructional designers [67]. Figure 13 represents the hierarchy of the methodological nodes identified in the documentary sample.

The second most frequent term in the studies about e-learning in the analyzed period was Structural Equation Modelling (SEM). This statistical methodology allows, through hypothesis testing, confirming a structural theory related to an educational phenomenon. This theory represents a causal process derived from multiple variables that are analyzed through regression equations and graphically represented with the aim of clarifying the studied theory. The theoretical model can be statistically verified in a simultaneous analysis of the entire system of variables to establish the degree of coherence with the data [110]. In the analyzed articles, there are two preferential uses of SEM: (a) Confirmation of theoretical models in non-experimental research, where other methods to examine the validity of the theories are not well developed $[38,42,111-116]$ and (b) the study of the validity and reliability of instruments used to measure e-learning [88].

Logistic regression is a statistical method used in empirical studies that involve categorical (dichotomic) dependent variables. Niu [117] states that, although logistic regression is an efficient tool to understand correlational relationships, some of the results reported in educational investigations based on logistic regression results might not be accurate and should be interpreted with caution. The research themes about e-learning with this methodology include the online student profile in higher education $[118,119]$ and self-regulated learning [120-122]. 


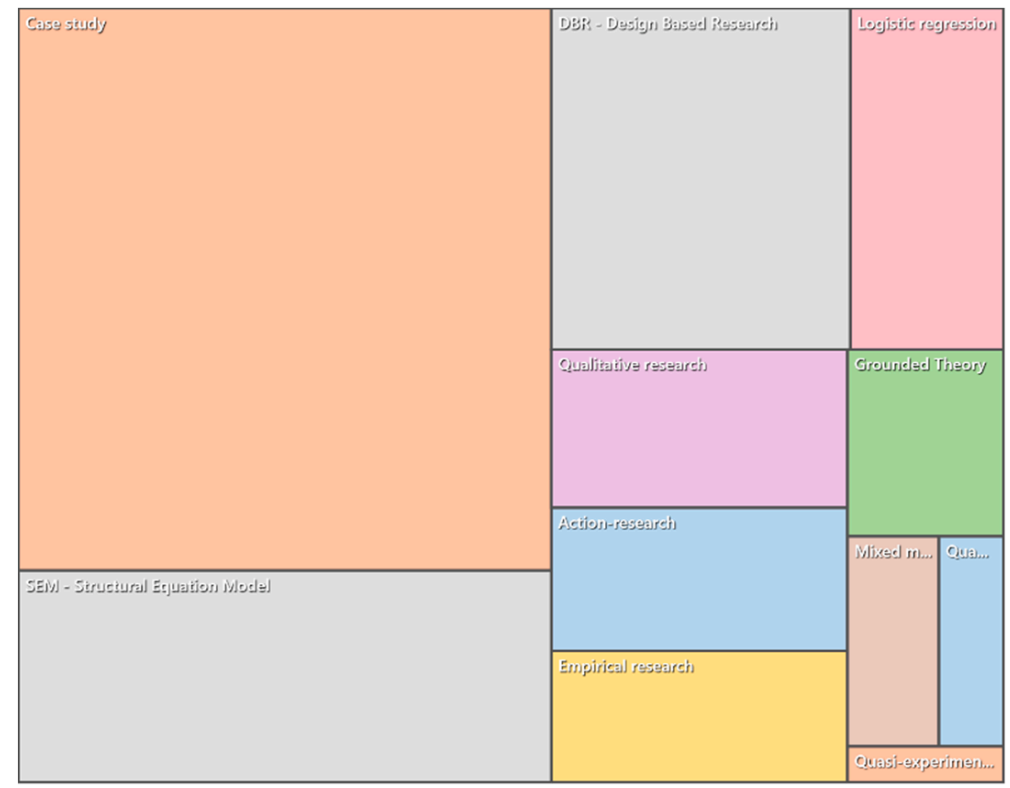

Figure 13. Hierarchy chart of nodes «Research methodology». Source: Developed by author using NVivo.

Another concept linked to educational research methodology is Design-Based Research (DBR). This concept includes a set of methodological approaches characterized by the design of educational environments or resources as an integral part of research, with the aim of contributing to the resolution of an educational problem or to the improvement of the teaching-learning process. DBR is organized in three phases, within a flexible and iterative structure: Analysis-exploration, design-construction, and evaluation-reflection. It allows exploring the possibilities of creating novel teaching and learning environments [123]. Consequently, in a DBR, educational interventions are conceptualized (designed) and then implemented in an iterative process, within real educational ecosystems, where the ecological validity of the theory is tested, and new theories are generated [124,125]. Its application in the research on e-learning is oriented toward the design of exemplars (modelling of pedagogical practices) [126], validation of teaching innovations [127,128], and usability [129].

Other concepts about qualitative methodologies with presence in the analyzed articles are Grounded Theory $[50,130,131]$ and Action-Research [132]. Figure 14 shows the percentage distribution of the nodes about research methodology in the journals analyzed in this SLR.

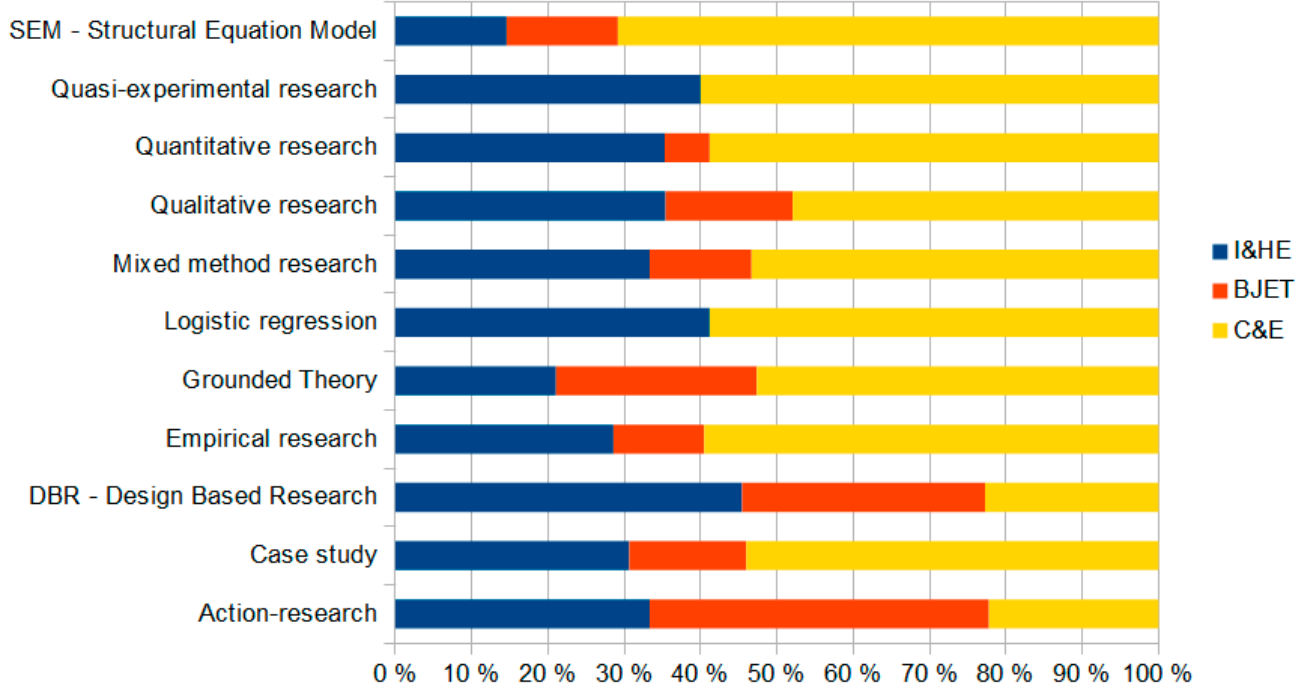

Figure 14. Nodes about research methodology by journal. Source: Development by author. 


\section{Conclusions}

The purpose of the systematic review was to analyze the evolution of educational research on e-learning. From an exhaustive search in three specialized journals in Educational Technology we selected studies that would provide answers to the three established research objectives. The conclusions obtained in this paper in relation to the proposed objectives are set out below.

\section{O1. To identify the research topics about e-learning and education that were published in international high-impact scientific journals in the period of 2009-2018.}

Our results show that the keywords most frequently used in e-learning studies are: MOOC, Higher Education, Teaching-Learning Strategies, and Interactive Learning Environments. The interest in MOOCs is oriented towards research in Learning Analytics and Social Networks Analysis. The educational level on which further research is carried out is Higher Education. Other educational levels that are also studied are Secondary Education and Adult Learning. Teaching-Learning Strategies focus on evaluation methodologies and self-regulated learning. Lastly, Interactive Learning Environments is a topic of e-learning research that deals especially with the development of learning communities (teaching and social presence) and about instructional design for computer-mediated communication (Evaluation of CAL System and Learning Management Systems).

From the analysis of the content of the selected articles, three main nodes are identified: (a) e-learning \& online students; (b) e-learning \& online teachers; and (c) e-learning \& curriculum. The e-learning \& online students node includes two main themes: self-regulation and dropout \& retention. The researchers' interest is focused on the main problems facing a distance education: The ability of students to regulate their own learning and how to achieve their permanence in these online learning contexts. The e-learning \& online teachers node includes two main subnodes: professional development (in-service teachers) and teacher education (pre-service teachers). The interest of researchers in training in teacher digital competence is verified. The node e-learning \& curriculum reveals impact \& success as the main research subtopic. Like any emerging educational modality, e-learning has to demonstrate its effectiveness in different dimensions of the educational process (organizational, economic, pedagogical). Other identified subtopics are «Course \& Learning management» and «Instructional Design».

\section{O2. To reveal the educational theories about e-learning that were used in international high-impact} scientific journals in the period of 2009-2018.

Community of Inquiry (CoI) emerges as the most relevant theoretical framework in the selected investigations. This theoretical model maintains that the construction of knowledge in virtual teaching-learning environments takes place by means of the development of a community that is characterised by three presences: Teaching, social, and cognitive. The Theory Acceptance Model (TAM) is other theoretical model with important presence in the analyzed articles. TAM predicts and explains the beliefs of teachers regarding the use of digital technologies in their teaching practice.

\section{O3. To determine the most used e-learning modality in studies published in international high-impact} scientific journals in the period of 2009-2018.

Massive Open Online Course (MOOC) is the e-learning modality with the greatest presence in the analyzed articles. The researchers are interested in demographic factors of online students and also for the identification of barriers, potentiators, and the definition of psychological profiles. A frequent object of study is the analysis of dropout. With respect to participation in MOOCs, expectations and motivations are analyzed. The students who participate in these courses have cognitive interests, but they are also motivated by the achievement of objectives such as certification and the improvement of their professional skills. Other topics that have emerged from our analysis are instructional design and discussion forums. 
O4. To identify the methodologies of educational research used in studies published in international high-impact scientific journals in the period of 2009-2018.

In the analyzed studies, investigations using qualitative methodologies predominate. Case study is the methodological concept most used in these research articles. It has been the most frequent method in studies on MOOCs with two typologies: observational case study and intervention-case study. The case study has also been used in research on online formative assessment. A significant presence of design-based research (DBR) has also been identified in the studies. Structural equation modelling (SEM) is the statistical methodology most used. Two main uses are identified: (a) Confirmation of theoretical models in non-experimental research and (b) the study of the validity and reliability of instruments.

In the SLR that we conducted, it was observed that, from 2009, the trend identified by Conole and Oliver [20] continues and the analyzed studies abandon technocentrism; that is, the research focused on devices and apps, to shift the focus toward the pedagogical process and its main agents: students, teachers, and curriculum.

Moreover, in line with our SLR, Shih et al. [21] also revealed the concept of interactive learning environment as one of the most frequent in the research on e-learning. Regarding the research methodology, most of the analyzed studies used descriptive methodologies, and the most frequent instrument for the gathering of data was the questionnaire. In this regard, our SLR shows that research on e-learning continues to apply qualitative methodologies, although it has gradually incorporated quantitative (v.gr. SEM) and mixed methods.

Also in line with the results of our SLR, Rodrigues et al. [15] highlighted concepts such as attention to personalized education, online student satisfaction and motivation. and the relevance of instructional planning and design for e-learning.

As can be observed, the review of Maurer and Khan [22] have some dimensions that are similar to the ones identified in our SLR, which, consequently, have persisted in time and are essential elements of the research objectives of studies about e-learning: Online student/teacher, instructional design, assessment, and interactive learning environment.

Just as in Oncu and Cakir's review [23], our SLR shows that research methods have been used in the scope of formative/developmental research, such as design-based research (DBR), and in the scope of activity theory, such as action-research. Experimental research is still poorly present due to the difficulties of its implementation in e-learning contexts.

Some of e-learning evaluation criteria identified by Zare et al. [19] are implicitly included in the categories and subcategories of our SLR. In the period analyzed in our review, the studies about MOOCs include evaluations of this e-learning model that consider these criteria.

Our SLR has some limitations. All the analyzed articles are written in English; therefore, future studies should consider including publications in other languages, since e-learning is a global educational phenomenon of interest to educational researchers all over the world, especially as a consequence of the effects of the COVID-19 pandemic on education systems. Moreover, it would be convenient to conduct similar SLRs about this topic approaching shorter periods, in order to obtain a more accurate and recent evolution of the research interests. These SLRs also must considered different educational, socio-economical, and cultural contexts.

Author Contributions: Conceptualization, J.V.-B. and M.d.C.G.-A.; methodology, J.V.-B. and M.d.C.G.-A.; software, J.V.-B.; validation, C.B.-V. and M.B.M.-C.; formal analysis, J.V.-B. and M.d.C.G.-A.; investigation, J.V.-B., M.d.C.G.-A, C.B.-V., and M.B.M.-C.; resources, J.V.-B. and M.d.C.G.-A.; data curation, C.B.-V. and M.B.M.-C.; writing-original draft preparation, J.V.-B.; writing-review and editing, M.d.C.G.-A.; visualization, C.B.-V. and M.B.M.-C.; supervision, J.V.-B.; project administration, M.d.C.G.-A.; funding acquisition, J.V.-B. All authors have read and agreed to the published version of the manuscript.

Funding: This study was funded by The Regional Government (Junta de Extremadura), grant number GR18071.

Acknowledgments: The authors are grateful to the Regional Government (Junta de Extremadura) for supporting the Research group under the SEJ035 code by the VII Action Plan 2018-2021 at the University of Extremadura through the European Funds (FSE and FEDER). 
Conflicts of Interest: The authors declare no conflict of interest.

\section{Appendix A}

Complete list of SRL references $(\mathrm{N}=248)$. Available at: https://zurbaran.unex.es/cloud/index.php/ s/BFs5kFDtt8fjNDC.

\section{References}

1. The World Bank World Bank Education and COVID-19. Available online: https:/www.worldbank.org/en/ data/interactive/2020/03/24/world-bank-education-and-covid-19 (accessed on 15 June 2020).

2. UNESCO COVID-19 Educational Disruption and Response. Available online: https://en.unesco.org/covid19/ educationresponse (accessed on 8 May 2020).

3. World Bank Individuals Using the Internet (\% of population) | Data. Available online: https://data.worldbank. org/indicator/IT.NET.USER.ZS?name_desc=false (accessed on 8 May 2020).

4. Bates, T. Crashing into online learning: A report from five continents-And some conclusions | Tony Bates. Available online: https://www.tonybates.ca/2020/04/26/crashing-into-online-learning-a-report-from-fivecontinents-and-some-conclusions/ (accessed on 8 May 2020).

5. Vázquez-Cano, E.; León Urrutia, M.; Parra-González, M.E.; López Meneses, E. Analysis of Interpersonal Competences in the Use of ICT in the Spanish University Context. Sustainability 2020, 12, 476. [CrossRef]

6. Statista E-learning and digital education. Available online: https://www.statista.com/topics/3115/e-learningand-digital-education/ (accessed on 8 May 2020).

7. World Commission on Environment and Development. Our Common Future; Oxford paperbacks; Oxford University Press: Oxford, UK, 1987; ISBN 978-0-19-282080-8.

8. Stepanyan, K.; Littlejohn, A.; Margaryan, A. Sustainable e-Learning: Toward a Coherent Body of Knowledge. J. Educ. Technol. Soc. 2013, 16, 91-102.

9. Stansfield, M.; Connolly, T.; Cartelli, A.; Jimoyiannis, A.; Magalhaes, H.; Maillet, K. The Identification of Key Issues in the Development of Sustainable e-Learning and Virtual Campus Initiatives. Electron. J. e-Learn. 2009, 7, 155-164.

10. Rovai, A.P.; Downey, J.R. Why Some Distance Education Programs Fail while Others Succeed in a Global Environment. Internet High. Educ. 2010, 13, 141-147. [CrossRef]

11. Chipere, N. A framework for developing sustainable e-learning programmes. Open Learn. J. Open Distance e-Learn. 2017, 32, 36-55. [CrossRef]

12. Aparicio, M.; Bacao, F.; Oliveira, T. An e-Learning Theoretical Framework. J. Educ. Technol. Soc. 2016, 19, 292-307.

13. Garrison, D.R. Blended Learning a Transformative Design Approach. In Encyclopedia of Distance Learning; Rogers, P.L., Ed.; Information Science Reference: Hershey, PA, USA, 2009; pp. 200-204. ISBN 978-1-60566-198-8.

14. Sangrà, A.; Vlachopoulos, D.; Cabrera, N. Building an inclusive definition of e-learning: An approach to the conceptual framework. Int. Rev. Res. Open Distrib. Learn. 2012, 13, 145-159. [CrossRef]

15. Rodrigues, H.; Almeida, F.; Figueiredo, V.; Lopes, S.L. Tracking e-learning through published papers: A systematic review. Comput. Educ. 2019, 136, 87-98. [CrossRef]

16. Garrison, D.R. E-learning in the 21st Century: A Community of Inquiry Framework for Research and Practice, 3rd ed.; Routledge: New York, NY, USA, 2017; ISBN 978-1-138-95355-0.

17. Dron, J.; Anderson, T. The future of e-learning. In The Sage Handbook of E-Learning Research; Haythornthwaite, C.A., Ed.; SAGE Reference: Los Angeles, CA, USA, 2016; pp. 537-556. ISBN 978-1-4739-0232-9.

18. Njenga, J.K.; Fourie, L.C.H. The myths about e-learning in higher education. Br. J. Educ. Technol. 2010, 41, 199-212. [CrossRef]

19. Zare, M.; Pahl, C.; Rahnama, H.; Nilashi, M.; Mardani, A.; Ibrahim, O.; Ahmadi, H. Multi-criteria decision making approach in E-learning: A systematic review and classification. Appl. Soft Comput. 2016, 45, 108-128. [CrossRef]

20. Conole, G.; Oliver, M. Contemporary Perspectives in e-Learning Research: Themes, Methods, and Impact on Practice; The open and flexible learning series; Routledge: London, UK; New York, NY, USA, 2007; ISBN 978-0-415-39393-5. 
21. Shih, M.; Feng, J.; Tsai, C.-C. Research and trends in the field of e-learning from 2001 to 2005: A content analysis of cognitive studies in selected journals. Comput. Educ. 2008, 51, 955-967. [CrossRef]

22. Maurer, H.; Salman Khan, M. Research trends in the field of e-learning from 2003 to 2008: A scientometric and content analysis for selected journals and conferences using visualization. Interact. Tech. Smart Ed. 2010, 7, 5-18. [CrossRef]

23. Oncu, S.; Cakir, H. Research in online learning environments: Priorities and methodologies. Comput. Educ. 2011, 57, 1098-1108. [CrossRef]

24. Moher, D.; Shamseer, L.; Clarke, M.; Ghersi, D.; Liberati, A.; Petticrew, M.; Shekelle, P.; Stewart, L.A. PRISMA-P Group Preferred reporting items for systematic review and meta-analysis protocols (PRISMA-P) 2015 statement. Syst. Rev. 2015, 4, 1. [CrossRef]

25. Shamseer, L.; Moher, D.; Clarke, M.; Ghersi, D.; Liberati, A.; Petticrew, M.; Shekelle, P.; Stewart, L.A. Preferred reporting items for systematic review and meta-analysis protocols (PRISMA-P) 2015: Elaboration and explanation. BMJ 2015, 349. [CrossRef]

26. Kohl, C.; McIntosh, E.J.; Unger, S.; Haddaway, N.R.; Kecke, S.; Schiemann, J.; Wilhelm, R. Online tools supporting the conduct and reporting of systematic reviews and systematic maps: A case study on CADIMA and review of existing tools. Environ. Evid. 2018, 7, 8. [CrossRef]

27. Cohen, J. A Coefficient of Agreement for Nominal Scales. Educ. Psychol. Meas. 1960, 20, 37-46. [CrossRef]

28. Landis, J.R.; Koch, G.G. The Measurement of Observer Agreement for Categorical Data. Biometrics 1977, 33, 159. [CrossRef]

29. van Eck, N.J.; Waltman, L. Software survey: VOSviewer, a computer program for bibliometric mapping. Scientometrics 2010, 84, 523-538. [CrossRef]

30. Lin, J.-W.; Huang, H.-H.; Chuang, Y.-S. The impacts of network centrality and self-regulation on an e-learning environment with the support of social network awareness. Br. J. Educ. Technol. 2015, 46, 32-44. [CrossRef]

31. Liaw, S.-S.; Huang, H.-M. Perceived satisfaction, perceived usefulness and interactive learning environments as predictors to self-regulation in e-learning environments. Comput. Educ. 2013, 60, 14-24. [CrossRef]

32. Sun, J.C.-Y.; Rueda, R. Situational interest, computer self-efficacy and self-regulation: Their impact on student engagement in distance education. Br. J. Educ. Technol. 2012, 43, 191-204. [CrossRef]

33. Cho, M.-H.; Kim, B.J. Students' self-regulation for interaction with others in online learning environments. Internet High. Educ. 2013, 17, 69-75. [CrossRef]

34. Hone, K.S.; El Said, G.R. Exploring the factors affecting MOOC retention: A survey study. Comput. Educ. 2016, 98, 157-168. [CrossRef]

35. Paton, R.M.; Fluck, A.E.; Scanlan, J.D. Engagement and retention in VET MOOCs and online courses: A systematic review of literature from 2013 to 2017. Comput. Educ. 2018, 125, 191-201. [CrossRef]

36. Lee, Y.; Choi, J.; Kim, T. Discriminating factors between completers of and dropouts from online learning courses. Br. J. Educ. Technol. 2013, 44, 328-337. [CrossRef]

37. Sun, J. Multi-dimensional alignment between online instruction and course technology: A learner-centered perspective. Comput. Educ. 2016, 101, 102-114. [CrossRef]

38. Lee, J.-W. Online support service quality, online learning acceptance, and student satisfaction. Internet High. Educ. 2010, 13, 277-283. [CrossRef]

39. Bradford, G.; Wyatt, S. Online learning and student satisfaction: Academic standing, ethnicity and their influence on facilitated learning, engagement, and information fluency. Internet High. Educ. 2010, 13, 108-114. [CrossRef]

40. Bradford, G.R. A relationship study of student satisfaction with learning online and cognitive load: Initial results. Internet High. Educ. 2011, 14, 217-226. [CrossRef]

41. Kim, C.; Park, S.W.; Cozart, J. Affective and motivational factors of learning in online mathematics courses. Br. J. Educ. Technol. 2014, 45, 171-185. [CrossRef]

42. Fryer, L.K.; Bovee, H.N. Staying motivated to e-learn: Person- and variable-centred perspectives on the longitudinal risks and support. Comput. Educ. 2018, 120, 227-240. [CrossRef]

43. Prior, D.D.; Mazanov, J.; Meacheam, D.; Heaslip, G.; Hanson, J. Attitude, digital literacy and self efficacy: Flow-on effects for online learning behavior. Internet High. Educ. 2016, 29, 91-97. [CrossRef]

44. Knutsson, O.; Blåsjö, M.; Hållsten, S.; Karlström, P. Identifying different registers of digital literacy in virtual learning environments. Internet High. Educ. 2012, 15, 237-246. [CrossRef] 
45. Bhuasiri, W.; Xaymoungkhoun, O.; Zo, H.; Rho, J.J.; Ciganek, A.P. Critical success factors for e-learning in developing countries: A comparative analysis between ICT experts and faculty. Comput. Educ. 2012, 58, 843-855. [CrossRef]

46. Moreno, V.; Cavazotte, F.; Alves, I. Explaining university students' effective use of e-learning platforms. Br. J. Educ. Technol. 2017, 48, 995-1009. [CrossRef]

47. Gökçearslan, Ş.; Alper, A. The effect of locus of control on learners' sense of community and academic success in the context of online learning communities. Internet High. Educ. 2015, 27, 64-73. [CrossRef]

48. Boling, E.C.; Hough, M.; Krinsky, H.; Saleem, H.; Stevens, M. Cutting the distance in distance education: Perspectives on what promotes positive, online learning experiences. Internet High. Educ. 2012, 15, 118-126. [CrossRef]

49. Stein, S.J.; Shephard, K.; Harris, I. Conceptions of e-learning and professional development for e-learning held by tertiary educators in New Zealand. Br. J. Educ. Technol. 2011, 42, 145-165. [CrossRef]

50. Wilson, A. Effective professional development for e-learning: What do the managers think? Br. J. Educ. Technol. 2012, 43, 892-900. [CrossRef]

51. Smith, J.A.; Sivo, S.A. Predicting continued use of online teacher professional development and the influence of social presence and sociability. Br. J. Educ. Technol. 2012, 43, 871-882. [CrossRef]

52. González-Gómez, F.; Guardiola, J.; Martín Rodríguez, Ó.; Montero Alonso, M.Á. Gender differences in e-learning satisfaction. Comput. Educ. 2012, 58, 283-290. [CrossRef]

53. Seale, J.; Cooper, M. E-learning and accessibility: An exploration of the potential role of generic pedagogical tools. Comput. Educ. 2010, 54, 1107-1116. [CrossRef]

54. Hung, M.-L.; Chou, C. Students' perceptions of instructors' roles in blended and online learning environments: A comparative study. Comput. Educ. 2015, 81, 315-325. [CrossRef]

55. Aparicio, M.; Bacao, F.; Oliveira, T. Cultural impacts on e-learning systems' success. Internet High. Educ. 2016, 31, 58-70. [CrossRef]

56. Cidral, W.A.; Oliveira, T.; Di Felice, M.; Aparicio, M. E-learning success determinants: Brazilian empirical study. Comput. Educ. 2018, 122, 273-290. [CrossRef]

57. Kruger-Ross, M.J.; Waters, R.D. Predicting online learning success: Applying the situational theory of publics to the virtual classroom. Comput. Educ. 2013, 61, 176-184. [CrossRef]

58. Hachey, A.C.; Wladis, C.; Conway, K. Prior online course experience and G.P.A. as predictors of subsequent online STEM course outcomes. Internet High. Educ. 2015, 25, 11-17. [CrossRef]

59. Arbaugh, J.B. Does academic discipline moderate CoI-course outcomes relationships in online MBA courses? Internet High. Educ. 2013, 17, 16-28. [CrossRef]

60. Margaryan, A.; Bianco, M.; Littlejohn, A. Instructional quality of Massive Open Online Courses (MOOCs). Comput. Educ. 2015, 80, 77-83. [CrossRef]

61. Chou, H.-L.; Chen, C.-H. Beyond identifying privacy issues in e-learning settings-Implications for instructional designers. Comput. Educ. 2016, 103, 124-133. [CrossRef]

62. Sung, Y.-T.; Chang, K.-E.; Yu, W.-C. Evaluating the reliability and impact of a quality assurance system for E-learning courseware. Comput. Educ. 2011, 57, 1615-1627. [CrossRef]

63. Arbaugh, J.B.; Godfrey, M.R.; Johnson, M.; Pollack, B.L.; Niendorf, B.; Wresch, W. Research in online and blended learning in the business disciplines: Key findings and possible future directions. Internet High. Educ. 2009, 12, 71-87. [CrossRef]

64. Yoo, S.J.; Huang, W.D. Can e-learning system enhance learning culture in the workplace? A comparison among companies in South Korea. Br. J. Educ. Technol. 2016, 47, 575-591. [CrossRef]

65. Broadbent, J. Comparing online and blended learner's self-regulated learning strategies and academic performance. Internet High. Educ. 2017, 33, 24-32. [CrossRef]

66. Michinov, N.; Brunot, S.; Le Bohec, O.; Juhel, J.; Delaval, M. Procrastination, participation, and performance in online learning environments. Comput. Educ. 2011, 56, 243-252. [CrossRef]

67. Gikandi, J.W.; Morrow, D.; Davis, N.E. Online formative assessment in higher education: A review of the literature. Comput. Educ. 2011, 57, 2333-2351. [CrossRef]

68. Guerrero-Roldán, A.-E.; Noguera, I. A model for aligning assessment with competences and learning activities in online courses. Internet High. Educ. 2018, 38, 36-46. [CrossRef]

69. Wang, T.-H. Developing an assessment-centered e-Learning system for improving student learning effectiveness. Comput. Educ. 2014, 73, 189-203. [CrossRef] 
70. Hew, K.F. Promoting engagement in online courses: What strategies can we learn from three highly rated MOOCS. Br. J. Educ. Technol. 2016, 47, 320-341. [CrossRef]

71. Garcia, R.; Falkner, K.; Vivian, R. Systematic literature review: Self-Regulated Learning strategies using e-learning tools for Computer Science. Comput. Educ. 2018, 123, 150-163. [CrossRef]

72. Garrison, D.R.; Anderson, T.; Archer, W. The first decade of the community of inquiry framework: A retrospective. Internet High. Educ. 2010, 13, 5-9. [CrossRef]

73. Garrison, D.R.; Anderson, T. E-learning in the 21st Century a Framework for Research and Practice; RoutledgeFalmer: London, UK; New York, NY, USA, 2003; ISBN 0-203-16609-4.

74. Thomas, R.A.; West, R.E.; Borup, J. An analysis of instructor social presence in online text and asynchronous video feedback comments. Internet and Higher Education 2017, 33, 61-73. [CrossRef]

75. Shea, P.; Bidjerano, T. Community of inquiry as a theoretical framework to foster "epistemic engagement" and "cognitive presence" in online education. Comput. Educ. 2009, 52, 543-553. [CrossRef]

76. Joo, Y.J.; Lim, K.Y.; Kim, E.K. Online university students' satisfaction and persistence: Examining perceived level of presence, usefulness and ease of use as predictors in a structural model. Comput. Educ. 2011, 57, 1654-1664. [CrossRef]

77. Joksimovic, S.; Gasevic, D.; Kovanovic, V.; Adesope, O.; Hatala, M. Psychological characteristics in cognitive presence of communities of inquiry: A linguistic analysis of online discussions. Internet High. Educ. 2014, 22, 1-10. [CrossRef]

78. Shea, P.; Bidjerano, T. Learning presence as a moderator in the community of inquiry model. Comput. Educ. 2012, 59, 316-326. [CrossRef]

79. Kozan, K.; Caskurlu, S. On the Nth presence for the Community of Inquiry framework. Comput. Educ. 2018, 122, 104-118. [CrossRef]

80. Rubin, B.; Fernandes, R.; Avgerinou, M.D. The effects of technology on the Community of Inquiry and satisfaction with online courses. Internet High. Educ. 2013, 17, 48-57. [CrossRef]

81. Kim, J.; Kwon, Y.; Cho, D. Investigating factors that influence social presence and learning outcomes in distance higher education. Comput. Educ. 2011, 57, 1512-1520. [CrossRef]

82. Zhan, Z.; Mei, H. Academic self-concept and social presence in face-to-face and online learning: Perceptions and effects on students' learning achievement and satisfaction across environments. Comput. Educ. 2013, 69, 131-138. [CrossRef]

83. Borup, J.; West, R.E.; Graham, C.R. Improving online social presence through asynchronous video. Internet High. Educ. 2012, 15, 195-203. [CrossRef]

84. Ke, F. Examining online teaching, cognitive, and social presence for adult students. Comput. Educ. 2010, 55, 808-820. [CrossRef]

85. Stenbom, S. A systematic review of the Community of Inquiry survey. Internet High. Educ. 2018, 39, $22-32$. [CrossRef]

86. Kovanović, V.; Joksimović, S.; Poquet, O.; Hennis, T.; Čukić, I.; de Vries, P.; Hatala, M.; Dawson, S.; Siemens, G.; Gašević, D. Exploring communities of inquiry in Massive Open Online Courses. Comput. Educ. 2018, 119, 44-58. [CrossRef]

87. Swan, K.; Matthews, D.; Bogle, L.; Boles, E.; Day, S. Linking online course design and implementation to learning outcomes: A design experiment. Internet High. Educ. 2012, 15, 81-88. [CrossRef]

88. Yu, T.; Richardson, J.C. Examining reliability and validity of a Korean version of the Community of Inquiry instrument using exploratory and confirmatory factor analysis. Internet High. Educ. 2015, 25, 45-52. [CrossRef]

89. Bagozzi, R.P.; Davis, F.D.; Warshaw, P.R. Development and Test of a Theory of Technological Learning and Usage. Hum. Relat. 1992, 45, 659-686. [CrossRef]

90. Cheung, R.; Vogel, D. Predicting user acceptance of collaborative technologies: An extension of the technology acceptance model for e-learning. Comput. Educ. 2013, 63, 160-175. [CrossRef]

91. Chang, C.-T.; Hajiyev, J.; Su, C.-R. Examining the students' behavioral intention to use e-learning in Azerbaijan? The General Extended Technology Acceptance Model for E-learning approach. Comput. Educ. 2017, 111, 128-143. [CrossRef]

92. Liu, I.-F.; Chen, M.C.; Sun, Y.S.; Wible, D.; Kuo, C.-H. Extending the TAM model to explore the factors that affect Intention to Use an Online Learning Community. Comput. Educ. 2010, 54, 600-610. [CrossRef] 
93. Ros, S.; Hernández, R.; Caminero, A.; Robles, A.; Barbero, I.; Maciá, A.; Holgado, F.P. On the use of extended TAM to assess students' acceptance and intent to use third-generation learning management systems. Br. J. Educ. Technol. 2015, 46, 1250-1271. [CrossRef]

94. Spector, J.M. A Critical Look at MOOCs. In Open Education: From OERs to MOOCs; Jemni, M., Kinshuk, Khribi, M.K., Eds.; Lecture Notes in Educational Technology; Springer: Berlin/Heidelberg, Germany, 2017; pp. 135-148. ISBN 978-3-662-52923-2.

95. Zhu, M.; Sari, A.; Lee, M.M. A systematic review of research methods and topics of the empirical MOOC literature (2014-2016). Internet High. Educ. 2018, 37, 31-39. [CrossRef]

96. van de Oudeweetering, K.; Agirdag, O. Demographic data of MOOC learners: Can alternative survey deliveries improve current understandings? Comput. Educ. 2018, 122, 169-178. [CrossRef]

97. Terras, M.M.; Ramsay, J. Massive open online courses (MOOCs): Insights and challenges from a psychological perspective. Br. J. Educ. Technol. 2015, 46, 472-487. [CrossRef]

98. Salmon, G.; Pechenkina, E.; Chase, A.-M.; Ross, B. Designing Massive Open Online Courses to take account of participant motivations and expectations. Br. J. Educ. Technol. 2017, 48, 1284-1294. [CrossRef]

99. Rieber, L.P. Participation patterns in a massive open online course (MOOC) about statistics. Br. J. Educ. Technol. 2017, 48, 1295-1304. [CrossRef]

100. Watted, A.; Barak, M. Motivating factors of MOOC completers: Comparing between university-affiliated students and general participants. Internet High. Educ. 2018, 37, 11-20. [CrossRef]

101. Barak, M.; Watted, A.; Haick, H. Motivation to learn in massive open online courses: Examining aspects of language and social engagement. Comput. Educ. 2016, 94, 49-60. [CrossRef]

102. Jung, Y.; Lee, J. Learning Engagement and Persistence in Massive Open Online Courses (MOOCS). Comput. Educ. 2018, 122, 9-22. [CrossRef]

103. Wise, A.F.; Cui, Y. Learning communities in the crowd: Characteristics of content related interactions and social relationships in MOOC discussion forums. Comput. Educ. 2018, 122, 221-242. [CrossRef]

104. Gillani, N.; Eynon, R. Communication patterns in massively open online courses. Internet High. Educ. 2014, 23, 18-26. [CrossRef]

105. Tømte, C.; Enochsson, A.-B.; Buskqvist, U.; Kårstein, A. Educating online student teachers to master professional digital competence: The TPACK-framework goes online. Comput. Educ. 2015, 84, 26-35. [CrossRef]

106. Tirado Morueta, R.; Maraver López, P.; Hernando Gómez, Á.; Harris, V.W. Exploring social and cognitive presences in communities of inquiry to perform higher cognitive tasks. Internet High. Educ. 2016, 31, 122-131. [CrossRef]

107. Lambropoulos, N.; Faulkner, X.; Culwin, F. Supporting social awareness in collaborative e-learning. Br. J. Educ. Technol. 2012, 43, 295-306. [CrossRef]

108. Boling, E.C.; Holan, E.; Horbatt, B.; Hough, M.; Jean-Louis, J.; Khurana, C.; Krinsky, H.; Spiezio, C. Using online tools for communication and collaboration: Understanding educators' experiences in an online course. Internet High. Educ. 2014, 23, 48-55. [CrossRef]

109. Raffaghelli, J.E.; Cucchiara, S.; Persico, D. Methodological approaches in MOOC research: Retracing the myth of Proteus. Br. J. Educ. Technol. 2015, 46, 488-509. [CrossRef]

110. Byrne, B.M. Structural Equation Modeling with Amos: Basic Concepts, Applications, and Programming, 3rd ed.; Multivariate applications series; Routledge, Taylor \& Francis Group: New York, NY, USA, 2016; ISBN 978-1-138-79702-4.

111. Joo, Y.J.; Lim, K.Y.; Park, S.Y. Investigating the structural relationships among organisational support, learning flow, learners' satisfaction and learning transfer in corporate e-learning. Br. J. Educ. Technol. 2011, 42, 973-984. [CrossRef]

112. Lee, Y.; Choi, J. A structural equation model of predictors of online learning retention. Internet High. Educ. 2013, 16, 36-42. [CrossRef]

113. Teo, T. A structural equation modelling of factors influencing student teachers' satisfaction with e-learning. Br. J. Educ. Technol. 2010, 41, E150-E152. [CrossRef]

114. Ulrich, J.; Karvonen, M. Faculty instructional attitudes, interest, and intention: Predictors of Web 2.0 use in online courses. Internet High. Educ. 2011, 14, 207-216. [CrossRef]

115. Lu, H.-P.; Chiou, M.-J. The impact of individual differences on e-learning system satisfaction: A contingency approach. Br. J. Educ. Technol. 2010, 41, 307-323. [CrossRef] 
116. Cho, V.; Cheng, T.C.E.; Lai, W.M.J. The role of perceived user-interface design in continued usage intention of self-paced e-learning tools. Comput. Educ. 2009, 53, 216-227. [CrossRef]

117. Niu, L. A review of the application of logistic regression in educational research: Common issues, implications, and suggestions. Educ. Rev. 2020, 72, 41-67. [CrossRef]

118. Ortagus, J.C. From the periphery to prominence: An examination of the changing profile of online students in American higher education. Internet High. Educ. 2017, 32, 47-57. [CrossRef]

119. Artino, A.R. Online or face-to-face learning? Exploring the personal factors that predict students' choice of instructional format. Internet High. Educ. 2010, 13, 272-276. [CrossRef]

120. Artino, A.R.; Stephens, J.M. Academic motivation and self-regulation: A comparative analysis of undergraduate and graduate students learning online. Internet High. Educ. 2009, 12, 146-151. [CrossRef]

121. Artino, A.R.; Jones, K.D. Exploring the complex relations between achievement emotions and self-regulated learning behaviors in online learning. Internet High. Educ. 2012, 15, 170-175. [CrossRef]

122. Kim, D.; Yoon, M.; Jo, I.-H.; Branch, R.M. Learning analytics to support self-regulated learning in asynchronous online courses: A case study at a women's university in South Korea. Comput. Educ. 2018, 127, $233-251$. [CrossRef]

123. The Design-Based Research Collective Design-Based Research: An Emerging Paradigm for Educational Inquiry. Educ. Res. 2003, 32, 5-8. [CrossRef]

124. Hathaway, D.; Norton, P. Understanding Problems of Practice. A Case Study in Design Research; SpringerBriefs in Educational Communications and Technology; Springer International Publishing: Cham, Switzerland, 2018; ISBN 978-3-319-77558-6.

125. Huang, R.; Spector, J.M.; Yang, J. Design-Based Research. In Educational Technology; Springer: Singapore, 2019; pp. 179-188. ISBN 9789811366420.

126. Hrastinski, S.; Keller, C.; Carlsson, S.A. Design exemplars for synchronous e-learning: A design theory approach. Comput. Educ. 2010, 55, 652-662. [CrossRef]

127. Rasi, P.; Vuojärvi, H. Toward personal and emotional connectivity in mobile higher education through asynchronous formative audio feedback. Br. J. Educ. Technol. 2018, 49, 292-304. [CrossRef]

128. Swan, K.; Day, S.L.; Bogle, L.R.; Matthews, D.B. A collaborative, design-based approach to improving an online program. Internet High. Educ. 2014, 21, 74-81. [CrossRef]

129. Chang, C. Usability testing for e-learning material for new employee training: A design-based research approach. Br. J. Educ. Technol. 2011, 42, E125-E130. [CrossRef]

130. de Freitas, A.S.; Bandeira-de-Mello, R. Managerial action and sensemaking in e-learning implementation in Brazilian business schools. Comput. Educ. 2012, 59, 1286-1299. [CrossRef]

131. Biasutti, M. The student experience of a collaborative e-learning university module. Comput. Educ. 2011, 57, 1865-1875. [CrossRef]

132. Swaggerty, E.A.; Broemmel, A.D. Authenticity, relevance, and connectedness: Graduate students' learning preferences and experiences in an online reading education course. Internet High. Educ. 2017, 32, 80-86. [CrossRef]

(C) 2020 by the authors. Licensee MDPI, Basel, Switzerland. This article is an open access article distributed under the terms and conditions of the Creative Commons Attribution (CC BY) license (http://creativecommons.org/licenses/by/4.0/). 